\title{
Revision of the Neotropical genus Sapranthus (Annonaceae)
}

\author{
G.E. Schatz ${ }^{1}$, P.J.M. Maas², H. Maas-van de Kamer², L.Y.T. Westra², J.J. Wieringa²
}

Key words

Annonaceae descriptions morphology Neotropics phylogeny Sapranthus taxonomy vernacular names

\begin{abstract}
A taxonomic revision of the genus Sapranthus is presented. Within the genus Sapranthus 8 species are recognized, 2 of which are new. Distinguishing morphological characteristics are discussed, and a dichotomous key to all species is given. The species treatments include descriptions, full synonymy, geographical and ecological notes, vernacular names, and taxonomic notes. Distribution maps are presented of all species, and a complete
\end{abstract} identification list of exsiccatae examined is included.

Published on 26 June 2018

\section{Preamble}

"The latter [flowers], when first opening, are of a very light green, but they gradually change into a very dark bluish black, and then emit a most powerful carrion-like odour, quite as disagreeable as that of some Stapelias, Aristolochias, and Aroideae." (Seemann 1866: 369).

"The rankest and filthiest smelling thing I ever smelled, has the odor of carrion." (M.E. Jones 24, 2 July 1892.)

"Flowers...with unpleasant odor, like that of dirty socks..." (D.A. Neill 3142, 9 Feb. 1978.)

"The dirty socks tree." (Organization for Tropical Studies, Tropical Biology: An Ecological Approach 82-1.)

\section{INTRODUCTION}

The genus Sapranthus was described and illustrated by Seemann in 1866, his generic name based upon the characteristic fetid odour of the flowers, which he had experienced in the field in Nicaragua. A second species was assigned to the genus by Fries (1900), followed by two additional species by Standley (1922), all transfers from other New World genera. At the time of the last revision, Fries $(1930,1931)$ recognized seven species based on only 23 collections. Fries (1948) subsequently described one more species, and thus enumerated eight species in the 'Die natürlichen Pflanzenfamilien' synthesis of the family Annonaceae (1959), while inexplicably omitting yet another new species described during the intervening years by Standley \& Steyermark (1943). More recently, two additional species of Sapranthus have been described with green flowers: S. viridiflorus from Mesoamerica (Schatz 1998), and S. isae from Colombia (Vélez-Arango \& Cogollo-Pacheco 2007). Based on the examination of over 520 exsiccatae, the current work recognizes 8 species of Sapranthus, including two new species.

\section{GENERAL MORPHOLOGY}

\section{Habit}

Species of Sapranthus are shrubs to small trees 1 to $15 \mathrm{~m}$ tall. The main trunk is relatively slender in species for which diameter

\footnotetext{
1 Missouri Botanical Garden, 4344 Shaw Blvd., St. Louis, Missouri, 63110, USA; corresponding author e-mail: george.schatz@mobot.org.

2 Naturalis Biodiversity Center, section Botany, P.O. Box 9517, 2300 RA Leiden, The Netherlands.
}

has been recorded, varying from 3-30 cm diam, rarely to 60 $\mathrm{cm}$ diam in S. palanga.

\begin{abstract}
Leaves
Leaves are simple, entire, petiolate, and estipulate, and arranged alternately in a single plane along lateral branches (distichous), and are usually deciduous. Petioles are shallowly canaliculate, and vary from $2-16 \mathrm{~mm}$ long. The shape of the lamina is elliptic to obovate, sometimes narrowly so. The texture of the lamina is membranous, the surface dull to shiny and usually smooth, but rarely weakly to strongly verruculose in $S$. microcarpus. The lamina varies in length from $5-34 \mathrm{~cm}$. The base of the lamina is attenuate to acute to obtuse, sometimes asymmetric or rarely subcordate in S. palanga. The apex of the lamina is generally acute to acuminate, the acumen to $20 \mathrm{~mm}$ long. The primary vein is usually distinctly impressed above. The venation is eucamptodromous to weakly brochidodromous with 5-14 secondary veins per side, with S. microcarpus exhibiting an unusually low number of secondary veins (5-8), as well as uniquely having pocket domatia in the axils of the secondary veins with the primary vein below; the tertiary venation is distinctly percurrent or less often reticulate in S. microcarpus. The indument on young branches, petioles and lamina is composed of simple, appressed or erect hairs, or in $S$. isae reported to be mixed with stellate hairs (Vélez-Arango \& Cogollo-Pacheco 2007). Most species of Sapranthus have leaves that are rather densely covered with both appressed and erect whitish hairs below; several species are distinguished by their indument: S. hirsutus by its long, whitish to golden brown hairs on the stems, petioles, and especially the primary vein below; and $S$. palanga by its stiff, short, erect hairs (hispid-strigose) rendering the lower surface of the lamina somewhat rough.
\end{abstract}

\section{Inflorescences}

Inflorescences are terminal rhipidia, usually appearing leaf-opposed by the overtopping of the renewal shoot, usually bearing a solitary flower (or rarely 2 flowers); flowers are occasionally borne on older wood or the main trunk in $S$. isae, S. violaceus, and $S$. viridiflorus, and in two species the rhipidia bear multiple flowers: a single flower at a time on a perennial short shoot just back from the leaves (ramiflory) (S. chiapensis), or a cluster of flowers at condensed perennial flowering nodes mostly on 
the main trunk from ground level on up (trunciflory) as well as on old lateral branches (ramiflory) (S. palanga). The pedicel (here measured as the entire stalk both below and above the articulation, i.e., including the peduncle) usually bears a single foliaceous ('leafy') bract 3 to $35 \mathrm{~mm}$ long at the articulation near the base of the pedicel to about midway to the flower, rarely with two bracts reported in $S$. isae. Pedicels vary in length from 5 to $40 \mathrm{~mm}$ (lengthening in fruit to $80 \mathrm{~mm}$ ), with shorter pedicels exhibited by $S$. chiapensis $(7-10 \mathrm{~mm})$ and $S$. isae $(5-8 \mathrm{~mm})$.

\section{Flowers}

Flowers are pendant, with 3 free sepals and 6 free petals in 2 equal to subequal whorls, the aestivation imbricate. The torus is convex and densely covered with erect hairs. Sepals exhibit evident venation, and vary in length from 4-22 $\mathrm{mm}$, with especially long sepals present in $S$. hirsutus $(15-22 \mathrm{~mm}$ ) and $S$. violaceus $(6-18 \mathrm{~mm})$. Petals are usually membranous with evident venation, or rarely fleshy coriaceous and lacking evident venation (S. viridiflorus) at anthesis, albeit exhibiting venation in bud and throughout much of development. Petals are dark purple brown or maroon or sometimes reddish or rarely green ( $S$. isae and $S$. viridiflorus) with purple tint at the base, and usually bear a corrugated, yellow, white or rarely black ( $S$. isae) food body at the base of the inner petals where they narrow to a short geniculate claw; in S. viridiflorus, the food body is rudimentary (perhaps vestigial?) and present as a small, triangular, white patch. Stamens are numerous, with a very short filament and a discoid connective apex. Carpels are free, generally numerous (only 1-6 in S. viridiflorus), the stigma is sessile or with a very short style, spherical to napiform to flattened ellipsoid, attached to the ovary obliquely. Ovules (3-23) are lateral in usually two rows, or rarely in a single row (S. microcarpus).

\section{Fruits}

Fruits are apocarpous, a cluster of 1-25 indehiscent berry-like monocarps, usually short-stipitate but sessile in $S$. campechianus and $S$. isae. The monocarps are usually ellipsoid to oblongoid to obovoid and mostly much larger than $20 \mathrm{~mm}$ diam, with two alternating rows of seeds, sometimes interdigitated and therefore giving the appearance of a single row; in S. microcarpus, with a single row of seeds, the monocarps are less than $20 \mathrm{~mm}$ diam and greatly resemble those of Desmopsis. The monocarps are green or yellow, sometimes maturing orange or red. Seeds vary in number from 1 to 19 , and are usually spherical wedge-shaped; in S. isae the seeds are flattened ellipsoid to spherical wedge-shaped, and in S. microcarpus they resemble those of Desmopsis and are either subspherical to ellipsoid if the monocarp has only a single seed, or discoid and hemispherical when the monocarp has two or more seeds. Seeds are smooth, or rarely pitted and slightly grooved ( $S$. isae), with the endosperm ruminations lamellate in four parts to peg-shaped.

\section{THE PHYLOGENETIC POSITION OF SAPRANTHUS WITHIN ANNONACEAE}

Sapranthus has been placed in tribe Miliuseae of subfamily Malmeoideae (Chatrou et al. 2012). Recent plastid phylogenies of tribe Miliuseae (Chaowasku et al. 2014, Ortiz-Rodriguez et al. 2016) have recovered Sapranthus in a clade of Mesoamerican taxa sister to Tridimeris, the two of them in turn sister to the Desmopsis alliance including Desmopsis (Schatz et al. 2018), Stenanona (Schatz \& Maas 2010), and several undescribed and unplaced taxa. This Mesoamerican clade of Miliuseae, which has been formally described as subtribe Sapranthinae (Ortiz-Rodriguez et al. 2016), is nested in a larger clade of Asian genera, and most closely related to an undescribed genus from
Thailand and Meiogyne. Sapranthus can be distinguished from Tridimeris (Schatz 1987) principally by its 3-merous flowers vs the 2-merous flowers of Tridimeris.

\section{Distinguishing characteristics of Sapranthus within Mesoamerican Miliuseae subtribe Sapranthinae}

Sapranthus can be distinguished from the other Mesoamerican genera with which it has been traditionally allied (Desmopsis, Stenanona, and Tridimeris) by its membranous petals with visible venation (clearly evident during development of the flowers of $S$. viridiflorus albeit lacking at anthesis), the three petals of the inner whorl possessing a fleshy, white to yellow (to reportedly black) 'food body' at their base (rudimentary in S. viridiflorus and resembling the white patch at the base of the inner petals of Tridimeris chiapensis M.A.Escobar \& Ortíz.-Rodr.). The food body serves as an attractant/food reward to visiting Coleoptera (Carabidae, Dermestidae, Tenebrionidae) that effect pollination (Schatz 1987, Olesen 1992). Studies of wood anatomy in four species of Sapranthus representing both sections of the genus (Ter Welle \& Van Rooden 1982) demonstrate that Sapranthus can be separated from either Desmopsis or Stenanona respectively on the basis of fewer aprotracheal parenchyma bands per millimeter (8.6-11.1 vs $10.9-13.8$ or $12.0-15.2)$, shorter vessel members $(222-336 \mu \mathrm{m}$ vs $360-423 \mu \mathrm{m}$ or $321-400 \mu \mathrm{m})$, and less tall rays $(834-1548 \mu \mathrm{m}$ vs $2070-3426 \mu \mathrm{m}$ or $1911-3195$ $\mu \mathrm{m})$. Pollen of Sapranthus is flattened ellipsoid in shape with two large sulci, i.e., disulcate, with smooth exine, whereas pollen of Desmopsis is boat-shaped with two more or less obscure sulci and a verrucate exine, and that of Stenanona is spherical and appears inaperturate also with a verrucate exine (Schatz 1987, Waha \& Hesse 1988, Waha \& Morawetz 1988).

\section{Sectional classification}

Fries (1930) divided Sapranthus into two sections (sect. Sapranthus and sect. Microsapranthus R.E.Fr.) based on flower size, the conspicuousness of petal venation, and the number of carpels and ovules. With the additional material now available, a distinct division of the genus into two groups is indeed clear, but is based on none of the above characters. Instead, the verruculose leaves with domatia, and bright orange, small, oblongoid to ellipsoid-oblongoid monocarps with discoid or hemispherical seeds in a single row of $S$. microcarpus (similar to those of Desmopsis) clearly set it apart from the rest of the genus, and it is thus retained as the sole member of sect. Microsapranthus. All other Sapranthus species lack verruculose leaves with domatia, and possess dull-coloured green to yellowish green (sometimes maturing orange or red), larger, ellipsoid-oblongoid to obovoid monocarps with spherical wedge-shaped or flattened ellipsoid seeds in two alternating and sometimes interdigitating rows, a morphology that suggests dispersal by mammals. At Santa Rosa in Guanacaste, Costa Rica, the seeming absence of a contemporary disperser of the fruit of $S$. palanga has led to the inclusion of Sapranthus in a guild of plant species perhaps formerly dispersed by a now extinct Pleistocene megafauna (Janzen \& Martin 1982, Janzen 1983).

\section{TAXONOMIC TREATMENT}

\section{Sapranthus}

Sapranthus Seem. (1866) 369, pl. 54. - Type: Sapranthus nicaraguensis Seem. (= Sapranthus violaceus (Sessé \& Moc. ex Dunal) Saff.).

Shrubs or small trees, often deciduous. Indument composed of simple or rarely stellate hairs. Young twigs terete, densely to sparsely covered with erect to appressed hairs. Leaves distichous, simple, entire, petiolate, estipulate, usually deciduous; petiole somewhat swollen, weakly to strongly canaliculate; 
lamina elliptic to broadly obovate, membranous, rarely verruculose, especially on the upper side, upper side sparsely to densely covered with erect or appressed hairs or glabrous, lower side sparsely to densely covered with erect or appressed hairs, rarely the hairs stiff and then the surface somewhat rough (hispid-strigose), base cuneate to rounded, occasionally somewhat inaequilateral and subcordate, apex obtuse to acuminate, primary vein impressed above, venation eucamptodromous to weakly brochidodromous with 5-14 secondary veins per side, rarely with domatia present in the axils of the secondary veins with the primary vein below, tertiary venation percurrent. Flowers bisexual, 3-merous, mostly solitary, terminal, but usually appearing leaf-opposed, or borne on the main trunk or older wood in condensed rhipidia; pedicel bearing a minute to broadly ovate foliaceous bract from nearly basal to midway, rarely with two distichous bracts; pedicels and outer side of bracts, sepals and petals glabrous to sparsely covered with appressed to erect hairs; flower buds conical; sepals 3 , free, imbricate, membranous, with evident venation; petals 6 , free, in two subequal whorls, imbricate, much longer than the sepals, membranous with evident venation, or rarely fleshy coriaceous and lacking venation at anthesis, cream yellow, reddish to deep maroon or less often green, the inner petals bearing a corrugated food body at their base inside, or rarely vestigial; stamens numerous, filaments very short, not septate, the anther connective expanded truncate discoid to slightly rounded above the thecae, minutely muriculate to tuberculate; pollen isopolar, flattened ellipsoid, disulcate, the exine much reduced and smooth, or rarely very shallowly verrucate, not as reduced within the area of the sulcus; staminodes absent; carpels $2-38$, free, style absent or rarely very short, stigma spherical to napiform to flattened ellipsoid, attached to the ovary obliquely; ovules 3-23 in two rows, or rarely in one row. Fruit apocarpous, consisting of 1-25, indehiscent, fleshy to woody, sessile to shortly stipitate, ellipsoid to oblongoid, or obovoid to subspherical monocarps; seeds 1-19, in two alternating and sometimes interdigitating rows or rarely one row, spherical wedge-shaped or flattened ellipsoid, or rarely discoid, hemispherical or subspherical to broadly ellipsoid, light tan to pale brown to orange brown, smooth or rarely pitted and slightly grooved ( $S$. isae), endosperm ruminations lamellate in four parts to peg-shaped ( $n=9:$ S. palanga (Bawa 1978)).

Distribution - 8 species from Mexico to Colombia.

Habitat \& Ecology — In deciduous to semi-evergreen to rarely evergreen forest, from sea level to $1900 \mathrm{~m}$.

Note - The genus was given its name because of its usually fetid flowers.

Sapranthus Seem. sect. Sapranthus (as 'Eu-Sapranthus' in Fries 1930). - Type: Sapranthus nicaraguensis Seem. (= Sapranthus violaceus (Sessé \& Moc. ex Dunal) Saff.).

Lamina never verruculose; domatia in the axils of the lateral veins with the primary vein absent abaxially; ovules in two distinct rows. Monocarps ellipsoid-oblong to obovoid to spherical, usually larger than $20 \mathrm{~mm}$ diam (sometimes less in S. campechianus), green to greyish or yellow-green to sometimes orange or red at maturity, presumably adapted for mammal dispersal. Seeds spherical wedge-shaped or flattened ellipsoid.

Sapranthus Seem. sect. Microsapranthus R.E.Fr. (1930) 6 (as 'Micro-Sapranthus'). - Lecto (here designated): Sapranthus microcarpus (Donn.Sm.) R.E.Fr.

Lamina weakly to strongly verruculose, especially above; domatia present in the axils of the secondary veins with the primary vein below; ovules uniseriate. Monocarps subspheri- cal to oblongoid to ellipsoid-oblongoid, at most $20 \mathrm{~mm}$ diam, berry-like, bright orange, presumably adapted for bird dispersal. Seeds subspherical to broadly ellipsoid, discoid or hemispherical if situated at the apex or base of the monocarp.

\section{KEY TO THE SPECIES}

1. Leaves usually verruculose, especially above; domatia usually present in the axils of the lateral veins with the primary vein below; seeds in one row, discoid, subspherical to broadly ellipsoid or hemispherical. - Mexico, Guatemala, El Salvador, Honduras . . . . . . . . . . 5. S. microcarpus

1. Leaves never verruculose; domatia in the axils of the lateral veins with the primary vein absent below; seeds in two interdigitated rows, spherical wedge-shaped or flattened

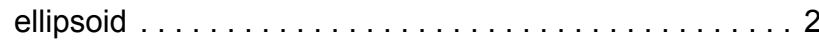

2. Indument on lamina of stiff, erect and appressed hairs (hispidstrigose) rendering the lower surface somewhat rough; flowers borne in clusters at condensed flowering nodes on old wood, primarily on the main trunk from near ground level on up (trunciflory). - Nicaragua, Costa Rica . 6. S. palanga

2. Indument on lamina of soft, appressed to erect hairs, the lower surface not at all rough; flowers solitary, terminal but appearing leaf-opposed, or rarely borne one at a time on perennial short shoots just back from the leaves (ramiflory) 3

3. Flowers borne on perennial short-shoots just back from the leaves (ramiflory); monocarps bearing lamellar, lacerate, plate-like excrescences to $10 \mathrm{~mm}$ high on their surface. Mexico (Chiapas) . . . . . . . . . . . . . 2. S. chiapensis

3. Flowers solitary, leaf-opposed or sometimes opposite leaf scar; surface of monocarps smooth $\ldots \ldots \ldots \ldots \ldots 4$

4. Indument on stems, lamina, and outer side of sepals and petals of erect and appressed, long (c. $2 \mathrm{~mm}$ ), whitish to golden brown hairs (hirsute); sepals $15-22$ by $11-16 \mathrm{~mm}$. Honduras, Nicaragua ... . . . . . . . . 3. S. hirsutus

4. Indument on stems, lamina, sepals and petals of appressed to erect, short (to c. $1 \mathrm{~mm}$ ), white to yellow hairs (tomentose or velutinous); sepals $4-8(-18)$ by $3-9(-15) \mathrm{mm} \ldots .5$

5. Monocarps sessile $\ldots \ldots \ldots \ldots \ldots \ldots \ldots \ldots \ldots$

5. Monocarps stipitate or rarely subsessile $\ldots \ldots \ldots \ldots 7$

6 . Bracts on the pedicel 1; petals red to brownish red at anthesis; monocarps 10-35 mm long; seeds smooth. - Mexico, Belize, Guatemala, Honduras ..... . 1. S. campechianus

6. Bracts on the pedicel 2; petals green with a purple tint at the base at anthesis; monocarps 33-48 mm long; seeds pitted to slightly grooved. - Colombia (Cesar) . . . . . 4. S. isae

7. Petals green with reddish purple tint at inner base inside at anthesis, thick coriaceous and lacking evident venation, $20-29$ by $5-15 \mathrm{~mm}$; number of monocarps $1-6$. - Nicaragua, Costa Rica, Panama ........ . 8. S. viridiflorus

7. Petals deep purple brown at anthesis, membranous and with evident venation, $25-120(-190)$ by $12-30(-70) \mathrm{mm}$; number of monocarps 10-25. - Mexico, Guatemala, El Salvador, Honduras, Nicaragua . . . . . . . 7. S. violaceus

\section{Sapranthus campechianus (Kunth) Standl. - Map 1}

Sapranthus campechianus (Kunth) Standl. (1922) 279. - Asimina campechiana Kunth (in Humboldt et al. 1821) 61 (as 'Asimia campechiana'). - Type: Humboldt \& Bonpland s.n. (lecto, here designated, P [P00322482]; iso B), Mexico, Campeche.

Asimina insularis Hemsl. (1886) 16, t. 1514 (as 'Asimia insularis') (incorrectly placed under the genus Anona [=Annona] as 'Anona insularis Hemsl.' in Millspaugh (1895) 17. - Type: Gaumer 71 (collection number not designated in protologue, but plate 1514 clearly based on such) (holo K), Mexico, Yucatán, Cozumel Island, 20 Apr. 1885. 
Tree or shrub 2-10 m tall, 3-30 cm diam; young twigs and petiole densely covered with erect and appressed, white hairs to c. $0.5 \mathrm{~mm}$ long. Leaves: petiole 2-9 $\mathrm{mm}$ long, 1-2 $\mathrm{mm}$ diam; lamina elliptic to obovate to narrowly so, $6-21$ by $3-9 \mathrm{~cm}$, rather densely covered with erect and appressed hairs, becoming sparsely so to glabrous above, densely covered with erect and appressed, white hairs below, base acute to obtuse, apex acute to acuminate (acumen 5-15 mm long), venation weakly brochidodromous, primary vein slightly impressed above, secondary veins $8-12$ on either side of primary vein, slightly raised to flat above, tertiary veins slightly raised to flat above, more or less percurrent. Inflorescence and flower indument: pedicels and outer side of bracts, sepals, and petals densely to rather densely covered with appressed and erect, white hairs. Flowers solitary, leaf-opposed; pedicels 5-20 mm long, c. $1 \mathrm{~mm}$ diam, to c. $3 \mathrm{~mm}$ diam in fruit; bract leafy, ovate-triangular, 3-30 by 3-15 mm; sepals c. 6 -veined, ovate-triangular, $4-8$ by $3-5$ $\mathrm{mm}$, finally reflexed; petals membranous, green, maturing red to brownish red, 5- or 6-veined, narrowly oblong-ovate, 20-40 by $5-12 \mathrm{~mm}$, base obtuse to rounded and ultimately truncate, c. $4 \mathrm{~mm}$ wide, abruptly narrowed into a geniculate claw, c. 3 by $2 \mathrm{~mm}$, the food body white, glistening, apex obtuse to acute with a rounded tip. Monocarps 2-11, green to yellow, maturing orange, ellipsoid, obovoid, to spherical, $10-35$ by $10-25$ $\mathrm{mm}$, densely to sparsely covered with erect, curly, white hairs, finally glabrous, wall 1-2 mm thick, stipes absent. Seeds 1-6, in one or two rows, spherical wedge-shaped, $10-15$ by $4-9$ $\mathrm{mm}$, smooth, pale brown.

Distribution - Mexico, Belize, Guatemala, Honduras.

Habitat \& Ecology - In low, dry, semideciduous forest. At elevations of $0-250(-1200) \mathrm{m}$. Flowering: March to June; fruiting: March to December.

Vernacular names - Belize: Bastard Custard Apple (Gentle 3980), Boy Job, Elemuy, Palanco, Sufricaya, Tuspi del monte (Arvigo 263). Guatemala: Anonilla (Contreras 5439), Ché ku'uk xib'al (Wallnöfer \& Tut-Testucun 5925, Maya name), Cojon de Venado, Nitxmaxche (Maya name), Saramuyo silvestre (Wallnöfer 9652, Itzá Maya name). Honduras: Palanco. Mexico: Anonillo, Chac Elemuy (Yucatán), Chacmax (Campeche), Chac Nich Max (Yucatán), Ganiste Tsub (Yucatán), Hazche (Yucatán), Kanistetsub (Quintana Roo), Lancewood (Yucatán) (Schott 559), Zac Elemuy (Yucatán).

Uses - 'Make a hedge around the house; to fasten the palm leaves on the roof of a house; fire wood' (Wallnöfer 9652, Guatemala).

Note - Fries (1930) included S. campechianus in his sect. Microsapranthus along with S. microcarpus because of its relatively smaller flowers with fewer carpels. However, with relatively larger monocarps and wedge-shaped seeds in two rows,

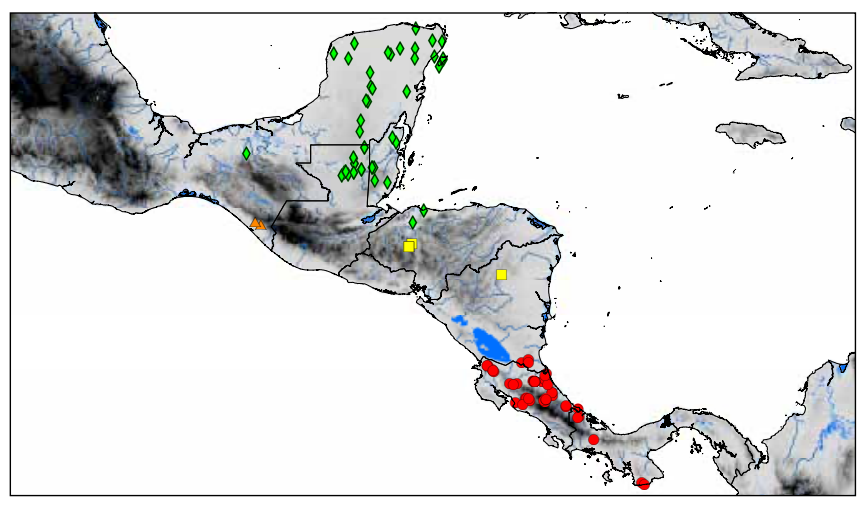

Map 1 Distribution of Sapranthus campechianus (Kunth) Standl. ( $\bullet$ ), S. chiapensis Standl. ex G.E.Schatz $(\mathbf{\Delta})$, S. hirsutus van Rooden ex G.E.Schatz (ם), and S. viridiflorus G.E. Schatz (O). and lacking verruculose leaves with domatia, S. campechianus is clearly more closely related to all other Sapranthus species than it is to $S$. microcarpus, and is therefore assigned herein to sect. Sapranthus. Within sect. Sapranthus, S. campechianus is distinguished by its small sepals ( $4-8 \mathrm{~mm}$ long), membranous, red petals and smooth, sessile monocarps.

\section{Sapranthus chiapensis Standl. ex G.E.Schatz, sp. nov. -} Fig 1a; Map 1

Sapranthus chiapensis is recognized by its flowers borne one at a time on perennial short shoots back from the leaves on older wood (ramiflorous), and its monocarps bearing plate-like, lamellar, lacerate excrescences to $10 \mathrm{~mm}$ tall. - Type: Matuda 16420 (holo MEXU [MEXU00013176]; iso F 2 sheets, K, MEXU, MICH, NY), Mexico, Chiapas, Jamaica, Escuintla, 24 Sept. 1946.

Shrub 4-5 m tall, diam not recorded; young twigs and petiole densely covered with mainly erect, pale golden brown hairs to c. $0.5 \mathrm{~mm}$ long. Leaves: petiole $4-11 \mathrm{~mm}$ long, c. $2 \mathrm{~mm}$ diam; lamina elliptic to elliptic-obovate, $5-20$ by $3-8 \mathrm{~cm}$, shiny and sparsely covered with appressed hairs above, densely covered with erect, white hairs below, base slightly asymmetric, acute to obtuse, apex acute to shortly acuminate (acumen to c. $5 \mathrm{~mm}$ long), venation weakly brochidodromous, primary vein slightly impressed above, secondary veins 11-13 on either side of primary vein, raised above, tertiary veins raised above, percurrent. Inflorescence and flower indument: pedicels and outer side of bracts, sepals, and petals sparsely to rather densely covered with appressed, white hairs. Flowers borne one at a time on perennial short shoots (rhipidia) on older wood back from the leaves, i.e., ramiflorous, the short shoots to c. $2 \mathrm{~cm}$ long; pedicels $7-10 \mathrm{~mm}$ long, c. $2 \mathrm{~mm}$ diam, fruiting pedicels to c. 18 $\mathrm{mm}$ long and c. $8 \mathrm{~mm}$ diam, densely covered with appressed hairs $0.4-0.6 \mathrm{~mm}$ long, bearing at its base a broadly ovate to orbicular bract, $6-7$ by $4-6 \mathrm{~mm}$, base obtuse to rounded, apex acute to obtuse, with evident venation; sepals broadly ovate to ovate, $12-13$ by $7-11 \mathrm{~mm}$, reflexed at anthesis, base truncate to concave and decurrent along the pedicel, apex acute, with evident venation; petals membranous, dark purple, with 5-7 longitudinal veins interconnected by faint cross veins, the former prominently raised on the outside, outer petals narrowly elliptic, $28-36$ by $10-16 \mathrm{~mm}$, concave, base cuneate, the point of attachment c. $4 \mathrm{~mm}$ broad, apex acute with a rounded tip, inner petals narrowly elliptic-oblong, $28-31$ by $10-13 \mathrm{~mm}$, base tapering abruptly and geniculate, forming a claw c. $3 \mathrm{~mm}$ long, c. $3 \mathrm{~mm}$ broad at the point of attachment, c. $5 \mathrm{~mm}$ wide at the point of the bend, with a corrugated food body present just above the claw inside consisting of c. 6 ridges separated by furrows, c. $4 \mathrm{~mm}$ long, c. $6 \mathrm{~mm}$ broad at its upper margin. Monocarps c. 6 (to potentially 20), greyish green, ellipsoid-oblongoid to obovoid, $10-63$ by $23-45 \mathrm{~mm}$, densely to sparsely covered with appressed hairs $0.3-0.4 \mathrm{~mm}$ long, bearing anastomosing, plate-like, lamellar, lacerate excrescences to c. $10 \mathrm{~mm}$ high, wall c. $0.5 \mathrm{~mm}$ thick, stipes $0-7 \mathrm{~mm}$ long. Seeds 4 or 5 , in one or two rows, spherical wedge-shaped, $18-22$ by $9-16 \mathrm{~mm}$, smooth, light tan.

Distribution - Mexico (Chiapas).

Habitat \& Ecology - In tropical dry deciduous forest. At elevations of c. $200 \mathrm{~m}$.

Vernacular names - Mexico: Haste, Pataste de Mico (Chiapas, Matuda 16420, 16466).

Other specimen examined. MExIco, Chiapas, Nueve Libertad, Escuintla Matuda 16466 (paratypes BR, F, MEXU 2 sheets, MICH).

Notes - Standley annotated the only two known collections of this species, both collected by Matuda, as Sapranthus chiapensis sp. nov. However, the name was never published, and we here adopt his epithet for this narrow Mexican endemic. With respect to leaf indument and floral characters, this distinctive 


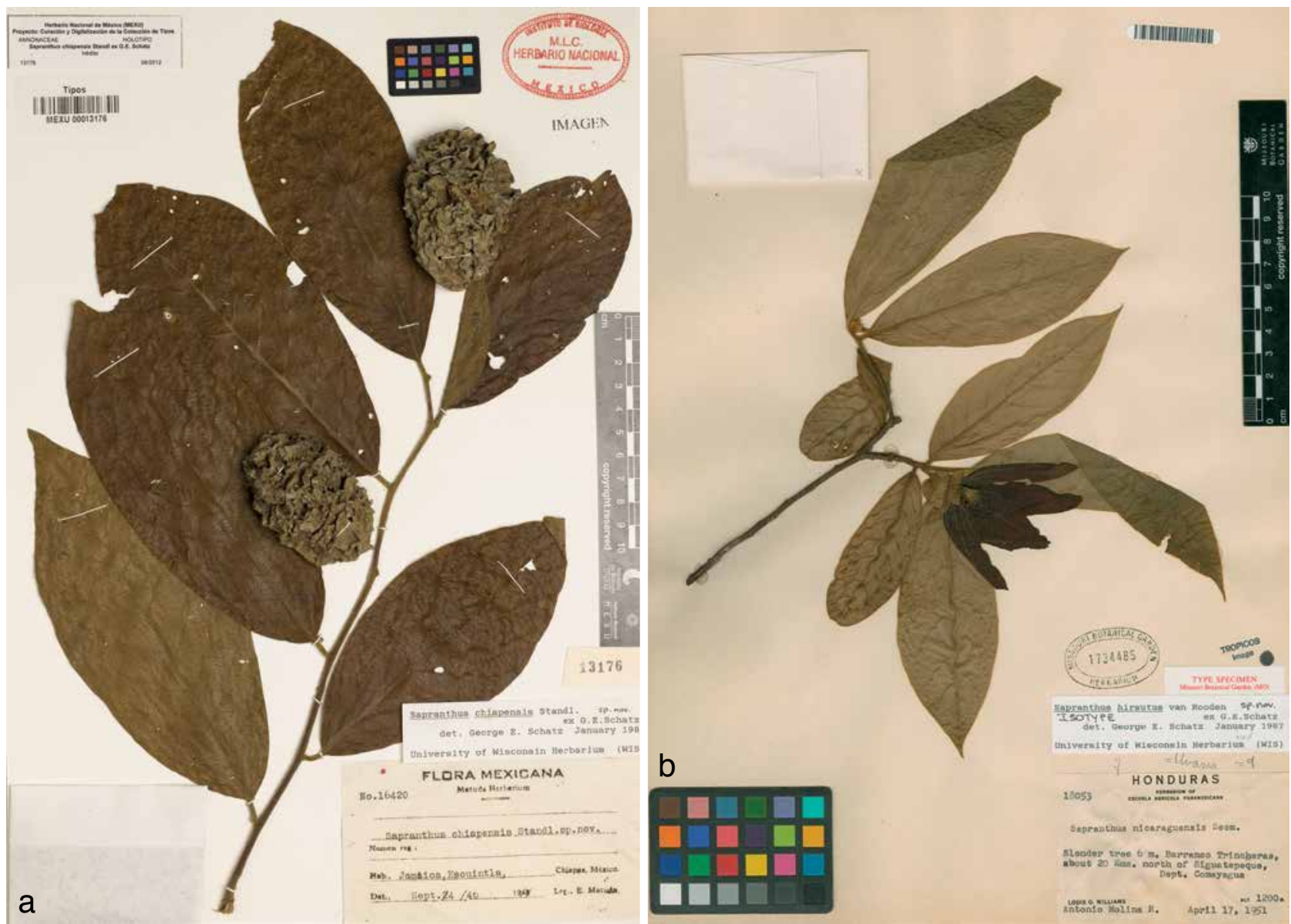

Fig. 1 a. Sapranthus chiapensis Standl. ex G.E.Schatz. Vegetative branch and fruit. - b. Sapranthus hirsutus van Rooden ex G.E.Schatz. Flowering branch (a: Matuda 16420, type, MEXU; b: Williams \& Molina R. 18053, type, MO).

species differs only slightly from the widespread Pacific dry forest $S$. violaceus. However, both the inflorescence structure, and the surface of the monocarps are unique within the genus. With the exception of $S$. palanga, whose flowers are borne at condensed flowering nodes primarily along the main trunk (trunciflory), all other Sapranthus species bear solitary, terminal flowers, which nonetheless appear leaf-opposed by extension of the renewal shoot. In contrast, S. chiapensis produces flowers, one at a time, on distinct short-shoots (rhipidia), these located on somewhat older branches just back of the leaves (ramiflory), a condition thus intermediate between S. palanga and all other Sapranthus species. At first glance, the surface sculpturing of the monocarps might appear to be an aberration, the possible result of disease. However, both collections exhibit identical plate-like excrescences. Although unique within Sapranthus, such monocarp surface sculpturing also occurs in several other Annonaceae including Stenanona costaricensis R.E.Fr. from Costa Rica and Nicaragua, as well as West African Piptostigma multinervium Engl. \& Diels and Monocarpia borneensis Mols \& Kessler in SE Asia.

\section{Sapranthus hirsutus van Rooden ex G.E.Schatz, sp. nov.} — Fig. 1b; Map 1

Sapranthus hirsutus is recognized by its densely hirsute young twigs, petioles, primary vein below, and both sepal and petal veins, and its large sepals 15-22 by $11-16 \mathrm{~mm}$. - Type: L. O. Williams \& Molina R. 18053 (holo MO [MO105994]; iso BM, F, GH, US), Honduras, Comayagua, Barranca Trincheras, about $20 \mathrm{~km} \mathrm{~N}$ of Siguatepeque, $1200 \mathrm{~m}, 17$ Apr. 1951.

Tree 5-15 m tall, diam not recorded; young twigs and petiole densely covered with erect and appressed, golden brownish hairs (hirsute) c. $2 \mathrm{~mm}$ long. Leaves: petiole 3-7 mm long, 1-3 $\mathrm{mm}$ diam; lamina narrowly elliptic to narrowly obovate, $8-27$ by $3-9 \mathrm{~cm}$, rather densely to sparsely covered with erect, golden brown hairs (hirsute) above, densely so below, base acute to obtuse, apex acute to acuminate (acumen 5-10 mm long), venation weakly brochidodromous, primary vein impressed above, secondary veins $9-13$ on either side of primary vein, slightly raised above, tertiary veins slightly raised above, percurrent to reticulate. Inflorescence and flower indument: pedicels and outer side of bracts, sepals, and petals densely to rather densely covered with erect and appressed, white hairs, and longer golden brown hairs above the veins on outer side of sepals and petals. Flowers solitary, leaf-opposed; pedicels 12-22 mm long, c. $2 \mathrm{~mm}$ diam; bract leafy, broadly ovate to ovate, $12-32$ by $12-19 \mathrm{~mm}$, base rounded to subcordate and somewhat ampexicaul and decurrent along the pedicel, apex acute; sepals distinctly veined, broadly ovate-triangular, 15-22 by 11-16 $\mathrm{mm}$, spreading; petals membranous, dark maroon, 5-7-veined, narrowly ovate to narrowly elliptic, $40-70$ by $10-25$ $\mathrm{mm}$, apex acute, inner petals bearing a corrugated food body at the base inside consisting of 6 ridges separated by 5 furrows, these connecting with the longitudinal veins; carpels c. 20, ovary densely covered with appressed hairs, ovules 7-12, in two rows, stigma subglobose to ellipsoid, c. $1 \mathrm{~mm}$ diam, obliquely attached to the ovary, sparsely covered with appressed hairs. Fruit and seeds unknown.

Distribution - Honduras, Nicaragua.

Habitat \& Ecology — In semideciduous forest at elevation of 1050-1200 m. Flowering: May; fruiting: unknown.

Vernacular names - Not recorded.

Field observations — 'Fls.... with a strong foetid odor' (Allen 6202). 
Other specimens examined. HondurAs, Comayagua, Barranca Trincheras, 1050 m, Allen 6202 (DS, F, GH); Barranca Trincheras, 3 km from Montañuela, 1200 m, Molina R. 13657 (F, LL, NY, US 2 sheets); 6 km after Siguatepeque, $3 \mathrm{~km}$ from Montañuela, near Canal 5 (radio station, $1100 \mathrm{~m}$, Van Rooden 850 (COL, F, K, MO, NY, P, S, U, W, WIS, WU 2 sheets). Nicaragua, Zelaya, Reserva Bosawas, Falda oeste del Cerro Salaya, entre el Campamento Los Monos y la cima, Grijalva et al. 5948 (MO).

Note - Van Rooden used the epithet 'hirsutus' for this taxon in a paper on wood anatomy (Ter Welle \& Van Rooden 1982: 17 ), but never validly published the name. We here adopt his epithet for this rare species known from two localities in Honduras and Nicaragua. Sapranthus hirsutus is clearly most closely related to the widespread Pacific dry forest species S. violaceus, from which the new species differs most markedly by its dense hirsute indument, which covers not only the lamina, but also bracts, sepals, and petals. In addition, its sepals are distinctly larger ( $15-22$ by $12-16 \mathrm{~mm})$ than those of $S$. violaceus $(6-18$ by $5-12 \mathrm{~mm}$ ), and in fact, are the largest in the genus.

\section{Sapranthus isae J.G.Vélez \& Cogollo - Map 2}

Sapranthus isae J.G.Vélez \& Cogollo (2007) 230, f. 1. - Type: Vélez-Arango, Cogollo \& Uribe 6668 (holo JAUM not seen; iso COL, CUVC, FMB, HUA, HUC, JBGP, TULV not seen), Colombia, Cesar, Mun. Curumani, Vereda El Champán, Cerro El Champán, 5 May 2005.

Tree 6-10 m tall, deciduous, diam not recorded; young twigs and petiole densely covered with yellow simple and stellate hairs. Leaves: petiole 8-10 long, 1-1.5 mm diam; lamina elliptic, $6.5-20$ by $3.5-9 \mathrm{~cm}$, with yellow simple and stellate hairs on both sides, base attenuate to acute to obtuse, apex acuminate, venation brochidodromous, primary vein impressed and covered with yellow hairs above, secondary veins 10-14 on either side of primary vein, impressed above, tertiary veins percurrent. Inflorescence and flower indument: pedicels and outer side of bracts, sepals, and petals sparsely to rather densely covered with yellow hairs. Flowers solitary, leaf-opposed or opposite leaf scar; pedicels $5-8 \mathrm{~mm}$ long, $2.5-3 \mathrm{~mm}$ diam, fruiting pedicels 8-15 mm long, 5-7 mm diam; bracts two, distichous, ovate to broadly ovate, the lower one $4.5-6$ by $4-6 \mathrm{~mm}$, the upper one $9-11$ by $7-8 \mathrm{~mm}$; sepals broadly ovate (triangular), 7-8 by 7-9 $\mathrm{mm}$, with indument more dense on the outer side; petals membranous, with evident venation at anthesis, green with a purple tint at the base inside and outside, with yellow indument more dense outside than inside, outer petals ovate, $15-30$ by 8-16 $\mathrm{mm}$, inner petals triangular, $21-37$ by $11-15 \mathrm{~mm}$, narrowed to a short claw with 4 or 5 rugose, strictly elliptic, black food bodies at the base inside. Monocarps 6-11, with odour of urine when dry, spherical to ellipsoid, $33-48$ by $26-33 \mathrm{~mm}$, (wall thickness not noted) with yellow indument coming off upon contact, exocarp black, mesocarp coffee-coloured; stipes absent. Seeds 4-7, in two rows, transversely broadly ellipsoid to

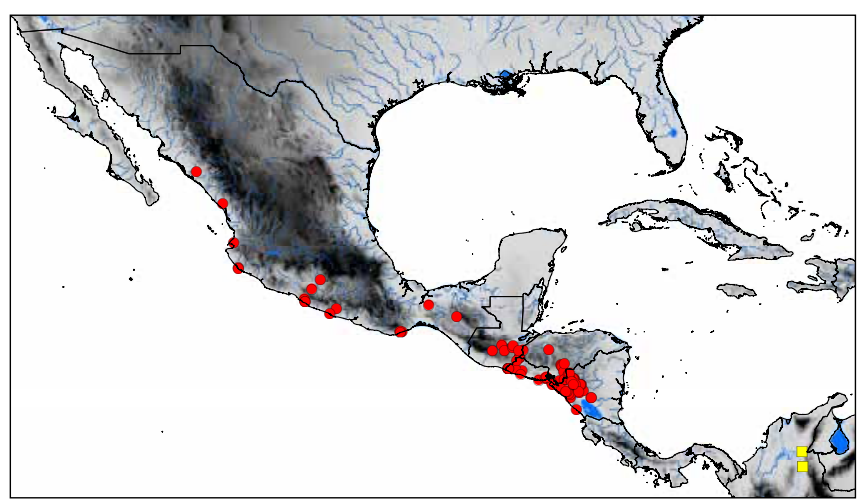

Map 2 Distribution of Sapranthus isae J.G.Vélez \& Cogollo ( $\mathbf{\square})$ and S. violaceus (Dunal) Saff. (). spherical wedge-shaped, $19-23$ by $6-13 \mathrm{~mm}$, coffee-coloured to reddish coloured, pitted to slightly grooved.

Distribution - Colombia (Cesar).

Habitat \& Ecology — In deciduous forest ('bosque caducifolio'), on rocky outcrops, surrounded by swampy areas, in association with Astronium graveolens, Bonamia trichantha, Bursera simaruba, Lonchocarpus atropurpureus, Machaerium mutisii, Oxandra venezuelana, Platymiscium polystachium, Pradosia colombiana, Sorocea affinis and Sterculia apetala. At elevations of 46-304 m. Flowering: May; fruiting: May, August to October.

Vernacular names - Not recorded.

Field observation - 'Flowers con olor fragrante' (VélezArango, Cogollo \& Uribe 6668, Colombia).

Note - Unfortunately, we were only able to see scans of $S$. isae, with all material of the species in Colombian herbaria. Based on the original description and our observations of the scans, $S$. isae is distinguished by its green flowers exhibiting venation at anthesis, borne on pedicels with two distichous bracts, and by its $6-11$ sessile monocarps.

\section{Sapranthus microcarpus (Donn.Sm.) R.E.Fr. - Fig. 2a; Map 3}

Sapranthus microcarpus (Donn.Sm.) R.E.Fr. (1900) 12. - Porcelia microcarpa Donn.Sm. (1895) 1. - Type: Donnell Smith 1484 (holo US; iso B, $\mathrm{GH}, \mathrm{K}, \mathrm{M}$, US 2 sheets), Guatemala, Quezaltenango, shores of Rio Ocosito, c. 100 m, Apr. 1892.

Asimina purpusii Brandegee (1913) 375 (as 'Asimina? purpusii'). — Type: Purpus 6276 (holo UC, not seen; iso BM, F, GH, MO, NY, US), Mexico, Veracruz, near Baños de Carrizal, Aug. 1912.

Sapranthus ligularis Saff. ex R.E.Fr. (1948) 14, t. 6a, b. - Type: Donnell Smith 4508 (leg. Heyde \& Lux) (holo US; iso GH, NY, S fragment), Guatemala, Sacatepequez ('Zacatepéquez'), Embaulada, 5500 p.p., Dec. 1889

Shrub or tree 1-15 m tall, c. $6 \mathrm{~cm}$ diam; young twigs and petiole rather densely covered with appressed and erect, white hairs to c. $0.5 \mathrm{~mm}$ long, soon glabrous. Leaves: petiole 3-6 mm long, $0.5-1 \mathrm{~mm}$ diam; lamina elliptic to obovate to narrowly so, 3-20 by $1.5-7.5 \mathrm{~cm}$, shiny above, glabrous or with a hairy primary vein above, rather densely to sparsely covered with appressed and erect, white hairs below, usually verruculose, especially on the upper surface, base obtuse to acute, apex acute, obtuse to shortly and bluntly acuminate (acumen to c. $10 \mathrm{~mm}$ long), venation weakly brochidodromous, primary vein impressed above, secondary veins $5-8$ on either side of primary vein, slightly raised above, mostly with pocket domatia in the axils of the secondary veins with the primary vein below, tertiary veins slightly raised to flat above, reticulate. Inflorescence and flower indument: pedicels and outer side of bracts and sepals densely to sparsely covered with appressed and erect hairs, petals sparsely so. Inflorescence 1- (or 2-)flowered, leaf-opposed; pedicels $10-40 \mathrm{~mm}$ long, $0.5-1 \mathrm{~mm}$ diam, to $\mathrm{c}$. $80 \mathrm{~mm}$ long

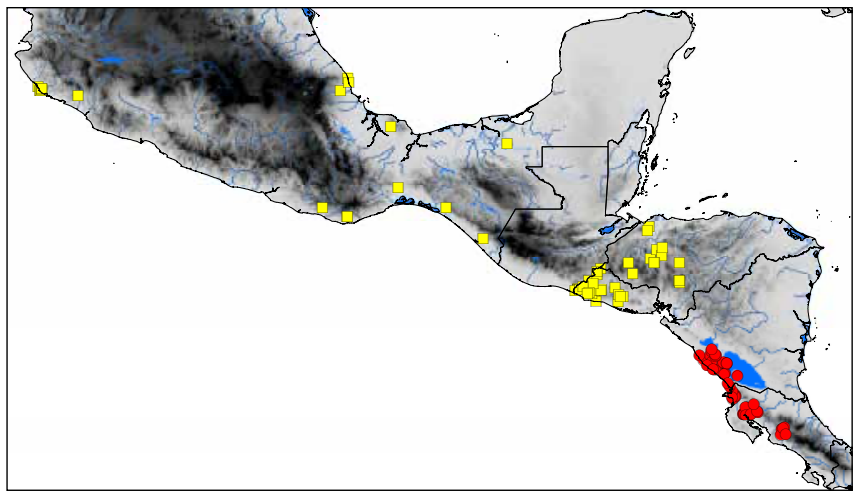

Map 3 Distribution of Sapranthus microcarpus (Donn.Sm.) R.E.Fr. (ם) and S. palanga R.E.Fr. (O). 

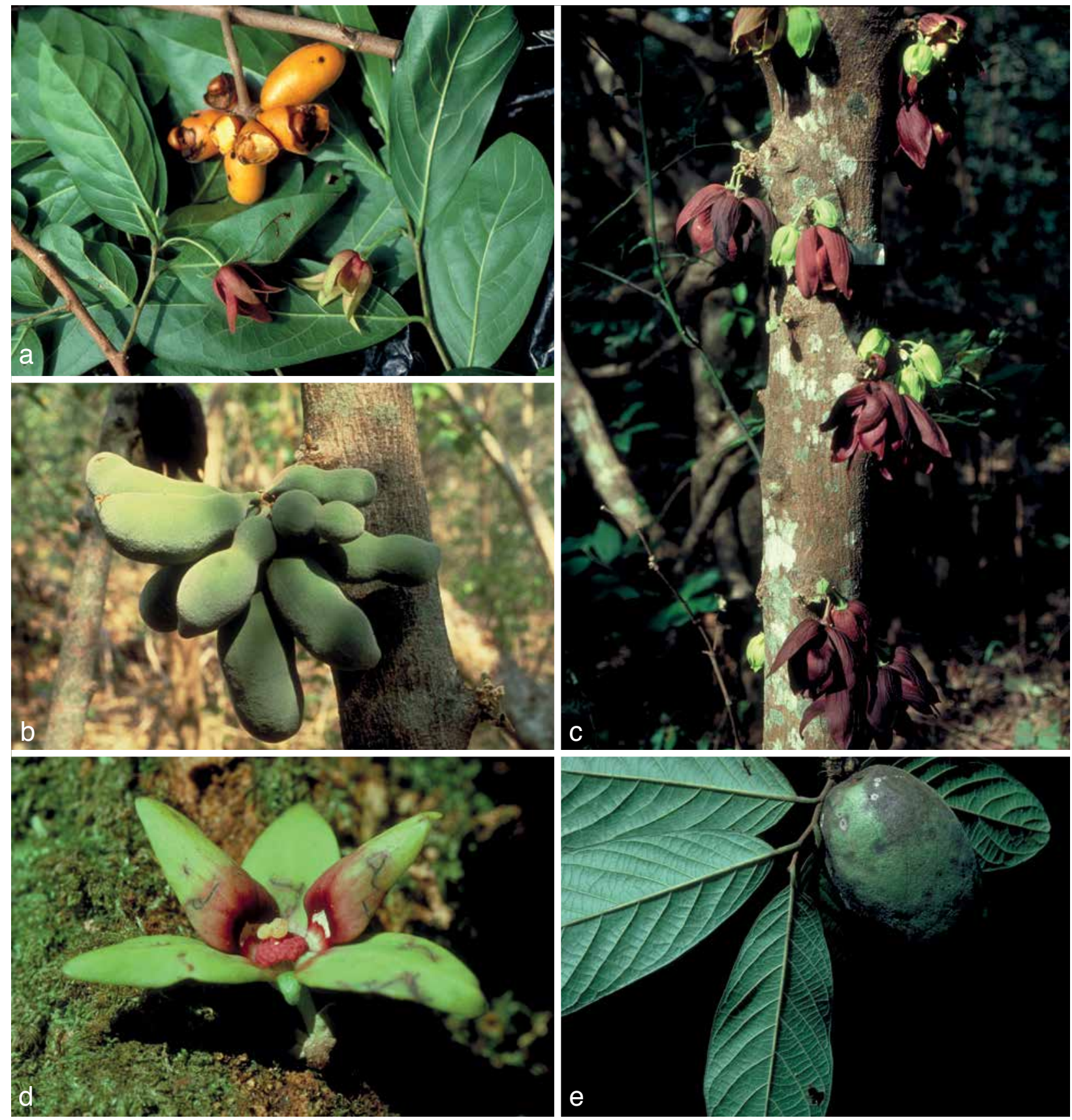

Fig. 2 a. Sapranthus microcarpus (Donn.Sm.) R.E.Fr. Flowering and fruiting branches. - b, c. Sapranthus palanga R.E.Fr. b. Fruit at Santa Rosa NP; c. flowering trunk at Santa Rosa NP. - d, e. Sapranthus viridiflorus G.E.Schatz. d. Flower; e. fruiting branch (a: Schatz 1199; b, c: without voucher; d: Schatz 963; e: Schatz 1031). — Photos by G.E. Schatz.

and 1-3 mm diam in fruit; bract leafy, ovate to broadly ovatetriangular, 3-33 by $2-13 \mathrm{~mm}$; sepals distinctly $5-10$-veined, narrowly triangular to triangular, $5-12$ by $3-5 \mathrm{~mm}$, spreading to reflexed; petals membranous, green, maturing cream-yellow with a purple blush at the base inside to pink or dull red to deep maroon, 2-6-veined, narrowly ovate, $15-35$ by $3-11 \mathrm{~mm}$, base tapering abruptly and forming a claw of c. 2 by $2 \mathrm{~mm}$, the food body c. 2 by $4 \mathrm{~mm}$, white, glistening. Monocarps 3-15, green, maturing orange, pulp fleshy, orange, subglobose to oblongoid to ellipsoid-oblongoid, $12-45$ by $10-20 \mathrm{~mm}$, rather densely covered with erect and appressed, minute, white hairs, wall 0.5-1 mm thick, stipes 1-4 mm long, 1-3 mm diam. Seeds 1-6, in one row, discoid, subspherical to broadly ellipsoid, or hemispherical, $8-12$ by $4-6 \mathrm{~mm}$, smooth to slightly grooved, pale brown.

Distribution - Mexico, El Salvador, Guatemala, Honduras.

Habitat \& Ecology — In tropical dry to moist forest. At elevations of $0-1100 \mathrm{~m}$. Flowering: May to July; fruiting: November, December, February.
Vernacular names - El Salvador: Asta (Rosales 466, 723, 1240, Sandoval 1455), Asta de bajillo (Martínez 56), Asta de costa (Chinchilla s.n.), Canjuro, Chufle, Guacoco blanco ó tresillo (Chinchilla s.n.), Hasta arbusto (Rosales 1902), Huevo de iguana (Chinchilla s.n), Palanco. Mexico: Anona (Torres 8323), Anonillo (Chiapas), Coloradillo (Schatz 1199, Veracruz), Colorado (Ibarra Manriquez 2164).

Uses - 'Medicinal para colicos' (Torres 8323, Mexico).

Field observations - 'Flores con olor suave, similar a las brácteas de los bananos' (Linares 7528, El Salvador); 'flowers with odour of rotting apples or fermented fruit' (Lott 3432, Mexico); 'flesh of fruit orange with a faint chlorine smell' (Monro 1951, El Salvador); 'fruit said to be eaten by Chachalacas' (Schatz 1199, Mexico).

Notes - Despite possessing typical flowers with evident petal venation, $S$. microcarpus differs markedly from all other Sapranthus species, and is here retained as the sole member of an emended sect. Microsapranthus, with S. campechianus 
reassigned to sect. Sapranthus, as discussed above. Sapranthus microcarpus is distinguished by its weakly to strongly verruculose leaves with domatia present on the lower side of the lamina in the axils of the secondary veins with the primary vein, and its brightly orange-coloured monocarps with mostly discoid seeds arranged in a single row, all characters unique within Sapranthus.

The types of Asimina purpusii Brandegee (Purpus 6276) and Sapranthus ligularis Saff. ex R.E.Fr. (Donnell Smith 4508) both possess a verruculose lamina with domatia, and thus clearly belong in S. microcarpus.

\section{Sapranthus palanga R.E.Fr. - Fig. 2b, c; Map 3}

Sapranthus palanga R.E.Fr. (1930) 12. - Type: Oersted 158 (holo C; iso BM, C 2 sheets, US), Costa Rica ('Nicaragua'), Guanacaste, 1845-48.

Sapranthus palanga R.E.Fr. var. santaerosae R.E.Fr. (1930) 13 (as 'Santae Rosae'). - Type: Oersted 157 (holo C), Costa Rica, Guanacaste, Hacienda Santa Rosa, Mar. 1847

Tree or shrub 3-12 m tall, 6-60 cm diam; young twigs and petiole densely covered with erect and appressed, white hairs to c. $1 \mathrm{~mm}$ long. Leaves: petiole $4-16 \mathrm{~mm}$ long, $1-4 \mathrm{~mm}$ diam; lamina obovate to elliptic, the first leaves of a shoot sometimes orbicular, $8-34$ by $4-18 \mathrm{~cm}$, densely covered with erect and appressed, stiff, white hairs to c. $1 \mathrm{~mm}$ long, soon subglabrous above, except for the primary vein, densely (at last rather densely) so below and therefore somewhat rough (hispid-strigose), base obtuse, sometimes subcordate, rarely acute, apex acute to shortly acuminate (acumen to c. $10 \mathrm{~mm}$ long), venation eucamptodromous, primary vein slightly impressed above, secondary veins $8-13$ on either side of primary vein, slightly raised above, tertiary veins slightly raised above, percurrent. Inflorescence and flower indument: pedicels and outer side of bracts and sepals densely covered with white erect and appressed, curly hairs, outer side of petals densely to sparsely so mainly along the longitudinal veins. Inflorescences condensed rhipidia mostly on the main trunk (trunciflory) and occasionally on leafless branches; pedicels 15-40 mm long, 1-2 mm diam, 3-5 mm diam in fruit; bract broadly ovate to broadly ovate-triangular, $5-11$ by $3-9 \mathrm{~mm}$; sepals distinctly 3 -veined, broadly ovate-triangular, $5-12$ by 5-11 mm, reflexed; petals membranous, green, maturing dark purple to black, 6-8-veined, narrowly elliptic to narrowly ovate, $70-110$ by $15-40 \mathrm{~mm}$, base rounded, concave, geniculate, the point of attachment c. $7 \mathrm{~mm}$ wide, apex acute to obtuse, inner petals narrowly elliptic to oblong, $80-100$ by $30-35 \mathrm{~mm}$, base cuneate and then abruptly narrowed to form a short claw, 4-7 $\mathrm{mm}$ broad, 1-2 $\mathrm{mm}$ thick at the point of attachment, concave, geniculate c. $3 \mathrm{~mm}$ from the base, the food body c. $7 \mathrm{~mm}$ at the middle to $6 \mathrm{~mm}$ at the margins, c. $3 \mathrm{~mm}$ from the base, i.e., just above the bend, consisting of 6 or 7 ridges separated by furrows, fleshy, cream to yellow, glistening, margins strongly revolute above the level of the food body, apex acute to obtuse. Monocarps 10-22, glaucous green, maturing red, globose, ellipsoid to oblongoid and somewhat curved, $60-125$ by $20-40$ $\mathrm{mm}$, sparsely covered with appressed to erect, curly hairs, wall c. $1 \mathrm{~mm}$ thick, stipes 5-22 $\mathrm{mm}$ long, 5-6 mm diam. Seeds $5-19$, in one or two rows, spherical wedge-shaped, 15-33 by 5-19 mm, smooth, pale brown.

Distribution - Nicaragua, Costa Rica.

Habitat \& Ecology - In tropical dry, deciduous forest. At elevations of $0-700 \mathrm{~m}$. Flowering: January to August; fruiting: January to July.

Vernacular names - Costa Rica: Guinea, Palanco (Pittier 1519, Tonduz 13796, Van Rooden 866), Platano, Turru. Nicaragua: Palanca/Palanco (Coronado 5716, 5964, 6285, Grijalva 815, 2424, Sandino 2811, Velásquez 230).
Field observations - 'Flowers smelling foetid' (Burger 11388, Costa Rica); 'flores..olor muy fuerte desagradable' (Chavarría 606, Costa Rica); 'olor a animal descompuesto' (Grijalva 2424); 'flores con olor a excremento de perro' (Hammel \& Morales 22451, Costa Rica); 'con olor fuerte y repelente' (Morales 2915, Nicaragua); 'de olor nauseabundo' (Sandino 1895, 1968, Nicaragua); 'unpleasant odour like that of dirty socks' (Neill 3142, Nicaragua); 'repumnante' (Moreno 15969, Nicaragua); 'flor hedionda' (Soza 407, Robleto 438, Nicaragua); 'flowers fetid smelling' (Stevens 31353-A, Nicaragua); 'flowers foul smelling' (Stevens 32796, Nicaragua).

Note - Sapranthus palanga is unique among Sapranthus species in possessing a hispid-strigose indument that renders the lower surface of the leaves somewhat rough. Although other Sapranthus species occasionally bear flowers on older wood (S. chiapensis), S. palanga is remarkable for its high degree of trunciflory, bearing flowers primarily along the main trunk from ground level on up, as well as occasionally on older leafless horizontal branches (ramiflory), but never among the leaves.

\section{Sapranthus violaceus (Dunal) Saff. — Fig. 3; Map 2}

Sapranthus violaceus (Dunal) Saff. (1911) 471. - Unona violacea Dunal (1817) 105, t. 25 [Fig. 3c]. - Type: Sessé \& Mociño Icon. Ined., 1787-1803 (fl) (lecto, designated by Maas et al. 1994, Torner Collection 1791 [Fig. 3a], Hunt Institute for Botanical Documentation, Pittsburgh PA; other original material: Torner Collection 1814 [Fig. 3b], Hunt Inst. Bot. Doc.; unnumbered Torner Collection drawing identical to 1791 but lacking handwriting, Hunt Inst. Bot. Doc.), Mexico-Nicaragua.

Sapranthus nicaraguensis Seem. (1866) 369, t. 54. - Porcelia nicaraguensis (Seem.) Benth. \& Hook.f. (1867) 956. - Uvaria nicaraguensis (Seem.) Baill. (1868) 195. - Asimina nicaraguensis (Seem.) Hemsl. (1887) 96. - Type: Seemann s.n. (or possibly Seemann 4 (BM) (holo K; iso BM, K), Nicaragua, Chontales, between Leon and Granada, no date.

Asimina foetida Rose (1897) 134. - Sapranthus foetidus (Rose) Saff. (in Standley 1922) 278. - Type: Palmer 394 (lecto (designated by Fries 1930) US 2 sheets; iso A, BM, F 2 sheets, GH, K, MO, UC), Mexico, Guerrero, Acapulco and vicinity, Feb. 1895

Sapranthus longipedunculatus R.E.Fr. (as 'Sapranthus longepedunculatus') (1930) 7, f. 1. - Type: Langlassé 128bis (holo K; iso B, P), Mexico, Guerrero, La Barranca, 150 m, 2 May 1898.

Sapranthus borealis R.E.Fr. (1930) 11, f. 2c. - Type: Gonzalez Ortega 856 (Narvaez, Montes \& Salazar 856) (holo K; iso K, MEXU 2 sheets, US), Mexico, Sinaloa, Arroyo del Palmar, La Caña, San Ignacio, 450 m, 3 June 1919. Sapranthus megistanthus Standl. \& Steyerm. (1943) 7. - Type: Standley 59219 (holo F; iso A, NY), Guatemala, Guatemala, on roadside bank, Estancia Grande, 600 m, 8 Dec. 1938.

Tree 3-12 m tall, to c. $30 \mathrm{~cm}$ diam; young twigs and petiole densely covered with erect and appressed, white, long-persisting hairs to c. $1 \mathrm{~mm}$ long. Leaves: petiole $3-13 \mathrm{~mm}$ long, 1-2 $\mathrm{mm}$ diam; lamina elliptic to obovate, $7-30$ by $3-12 \mathrm{~cm}$, sparsely covered with erect hairs mainly along the veins above, densely so along primary vein, densely covered with erect and appressed, white hairs to c. $1 \mathrm{~mm}$ long below, base obtuse to truncate, sometimes acute, apex acute to shortly acuminate (acumen to c. $5 \mathrm{~mm}$ long), venation weakly brochidodromous, primary vein impressed above, secondary veins $6-12$ on either side of primary vein, raised above, tertiary veins raised above, more or less percurrent. Inflorescence and flower indument: pedicels and outer side of bracts, sepals, and petals sparsely to rather densely covered with appressed, white hairs. Flowers solitary, occasionally produced from the main trunk; pedicels $6-43 \mathrm{~mm}$ long, c. $1 \mathrm{~mm}$ diam, to c. $6 \mathrm{~mm}$ diam in fruit; bract leafy, broadly ovate to triangular, $6-35$ by $3-22 \mathrm{~mm}$; sepals distinctly 5 - or 6 -veined, broadly ovate-triangular, $6-18$ by 5-15 mm, spreading to reflexed; petals membranous, deep purple brown at anthesis, 5-8-veined, narrowly elliptic, narrowly oblong-elliptic, to narrowly obovate, $25-120(-190)$ by $12-30(-70) \mathrm{mm}$, the venation prominently raised on the outer 

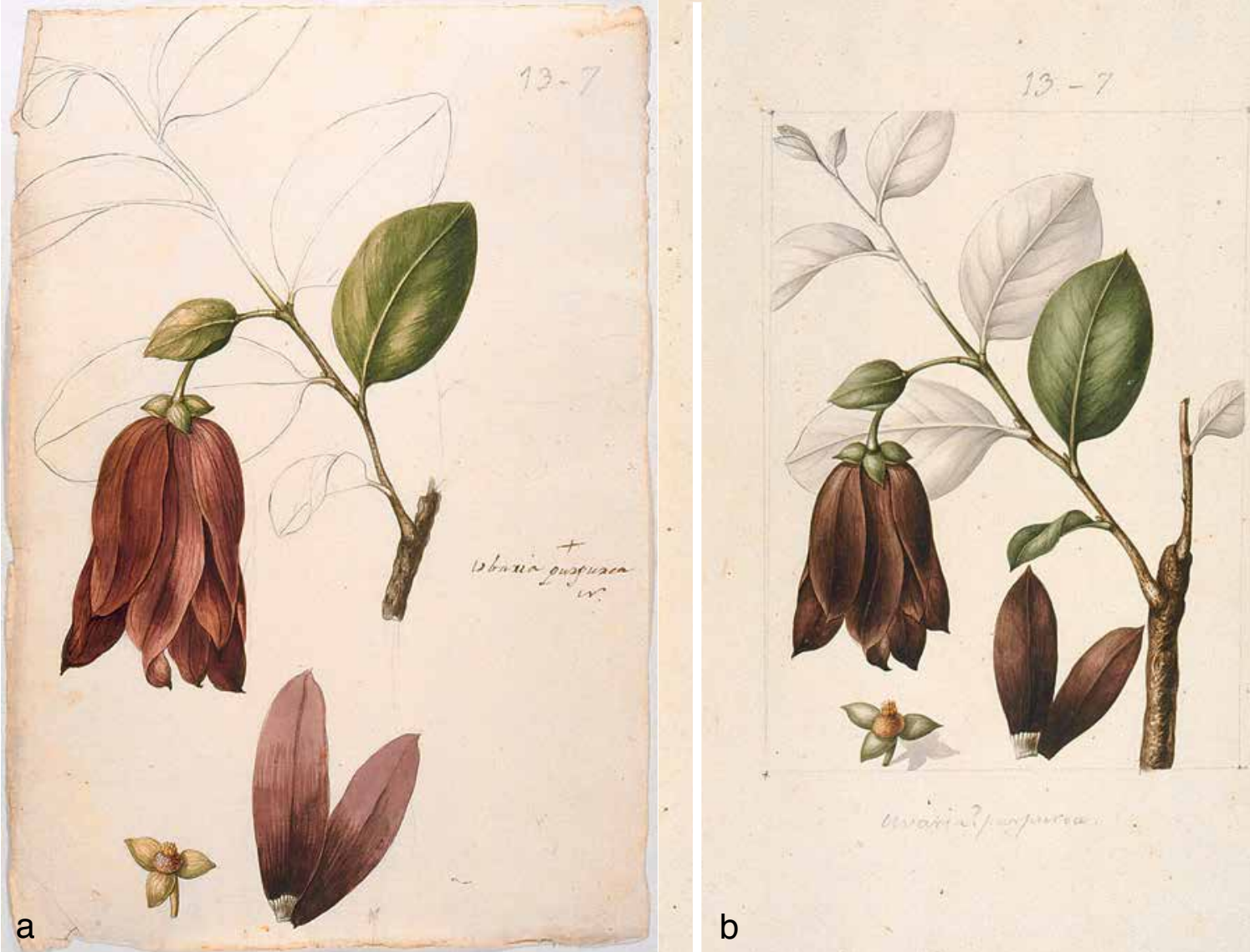

b
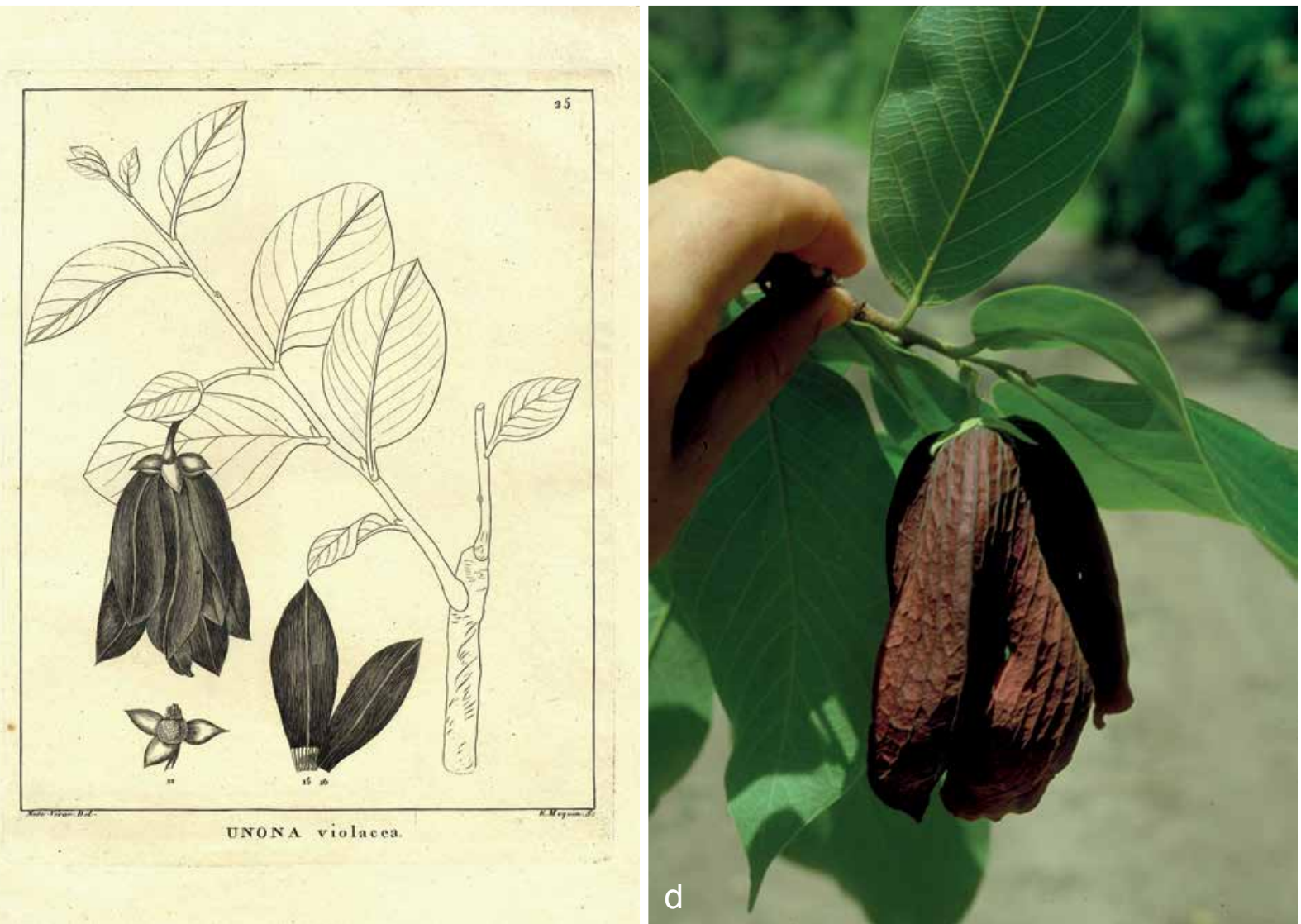

Fig. 3 Sapranthus violaceus (Dunal) Saff. Flowering branches (a: Torner Collection 1814, Hunt Institute for Botanical Documentation; b: Torner Collection 1791, Hunt Institute for Botanical Documentation, lectotype; c: Dunal (1817): t. 25; d: Schatz \& Stevens 587). — Photo d by G.E. Schatz. 
surface, base obtuse to cuneate, geniculate and abruptly narrowing to form a short claw, the food body cream-yellow, fleshy, glistening, apex obtuse to acute. Monocarps 10-25, glaucous green to brown, ellipsoid, oblongoid-ellipsoid to obovoid, 35-70 by $15-30 \mathrm{~mm}$, densely covered with appressed, curly, greyish hairs, creating a glaucous appearance, apex obtuse, wall 2-6 $\mathrm{mm}$ thick, stipes 2-8 $\mathrm{mm}$ long, 5-6 mm diam. Seeds 1-10, in one or two rows, spherical wedge-shaped, $10-21$ by $4-9 \mathrm{~mm}$, smooth, orange-brown.

Distribution - Mexico, Guatemala, El Salvador, Honduras, Nicaragua.

Habitat \& Ecology - In low, dry semideciduous forest. At elevations of $0-1200 \mathrm{~m}$. Flowering: all year through, but particularly May and June; fruiting: all year through.

Vernacular names - El Salvador: Anona blanca (Flores 394), Asta (López s.n., Rodríguez 2124, Rosales 447, 703, 738), Asta de costa (Sandoval s.n.), Asta de media altura (Martínez 876), Hasta (Martínez 625), Palanco (Witsberger 302). Guatemala: Palanco (Hazlett 2602). Honduras: Ala de murcielago (Molina R. 856). Mexico: Anonillo (Hinton 4564), Cacao (Hughes \& Elorsa 1916), Flora de mula negra (Kruse 1101), Morsiegalo (Langlassé 128bis), Platanito (Hughes \& Elorsa 1916), Zopilote (Hinton 9182), Zopilotillo (Ortega 856). Nicaragua: Palanca/Palanco (Coronado et al. 582, Grijalva et al. 1733, 2626, 2683, 4094, Rueda 11915, 13887, 15972, Sandino \& Aldubin 4393, Stevens 22420).

Field observations - 'Flores de aroma fuerte y nauseabundo' (Araquistain 3479, Nicaragua); 'flowers with the stink of rotting meat' (Davidse 30531, Nicaragua); 'flores moradas, olor desagradable' (Moreno 9436, Nicaragua); 'frutos verdes de olor extravagante' (Moreno 21967, Nicaragua); 'flowers with a strong rotting meat odor attracting flies flowers have a foul odor' (Rodríguez 2336, Vincelli 709, Nicaragua); 'flores fetidas' (Rueda 1191, Nicaragua); 'flor púrpura grande, con olor muy fuerte desagradable' (Sandino et al. 4393, 4426, 4437, Nicaragua); 'flowers with strong fetid odor' (Schatz \& Stevens 586, 587 , Stevens 30314 , Nicaragua); 'flowers producing a strong fetid odor and apparently heat, the flowers seemingly warmer than the surrounding air' (Stevens 20308, Nicaragua); 'flowers with a strong rotten meat odor attracting flies' (Stevens 28423, 29623, Nicaragua); 'fruits eaten' (Vincelli 480, Nicaragua).

Notes - Sapranthus violaceus can be recognized by an indument of short, whitish appressed and erect hairs, its solitary, usually leaf-opposed flowers (occasionally borne on older wood), quite large petals $(25-120(-190)$ by $12-30(-70) \mathrm{mm})$, and numerous stipitate monocarps (10-25).

Although Safford (1911) first signalled the correct generic placement of Dunal's (1817) Unona violacea by providing new combinations for both it and Asimina foetida in Sapranthus, Fries (1930: 11) was reluctant to recognize Unona violacea Dunal despite his statement that 'the plant is certainly a Sapranthus species'. Under his discussion of S. foetidus, Fries (1930) cites the pedicel in the Dunal illustration (Dunal 1817: t. 25, f. 4) as being too long for $S$. foetidus (and, therefore, why did it not correspond to his newly described species $S$. longepidunculatus?), and his having not examined a type specimen of Unona violacea, as justifications for not treating the Dunal species.

Ironically, however, Dunal based his description of Unona violacea, as well as those of Annona purpurea Sessé \& Moc. ex Dunal and Unona penduliflora [= Cymbopetalum penduliflorum (Dunal) Baill.], the three Annonaceae he described from the Sessé and Mociño Expedition to New Spain, solely on the drawings made during the expedition, which were brought to Montpellier by Mociño after he fled from Spain in 1813. They serve as the types for these three species (McVaugh 1980, 1982,1998 , Murray 1993). Unona violacea is represented by three of the Sessé \& Mociño drawings: one, a less polished field sketch (Torner Collection 1814 (Fig. 3a)) and two other nearly identical more finished drawings, one of which has been numbered Torner Collection 1791 (Fig. 3b), the other of which has been left unnumbered. These latter two drawings served as the model upon which the artist Node-Veran based his engraving for Dunal's Monograph, Plate 25 (Fig. 3c). The field sketch (Torner Collection 1814) has written on it in ink (the handwriting perhaps that of Mociño, 'Ubaria purpurea N', the 'b' presumably a linguistic transformation of a Spanish ' $v$ ', and hence indicating a new species and preliminary assignment to the genus Uvaria. The more finished drawing (Torner Collection 1791) has written in pencil below the drawing 'Uvaria? purpurea', the handwriting perhaps Dunal's. The nearly identical unnumbered drawing lacks any annotation. With the exception of failing to include the secondary cross venation in the petals and completing the three leaves cut off at their margins on the original drawing, Node-Veran accurately copied the drawing in preparation for the engraver. By the time the Monograph appeared in 1817, Dunal had rejected placement of the species in Uvaria, describing it instead as a Unona, with the epithet 'violacea' instead of 'purpurea'.

Insofar as the expedition drawings of $S$. violaceus are not part of the Icones Florae Mexicanae (a numbered series of species collected in western Mexico during the early part of the expedition), it is not possible to determine the exact provenance of the plants from which the drawings were made. In all likelihood they were encountered relatively late in the expedition during the travels of Mociño and the artist Cerda from Mexico to Costa Rica and back, during the period 1795-1799 (McVaugh 1977 and pers. comm.).

The five species brought together here in synonymy under $S$. violaceus have previously been distinguished on the basis of petal size and shape, and pedicel length, all of which vary greatly and continuously, both within an individual, and throughout the broad geographical range extending from Nicaragua north to Sinaloa, Mexico. For example, although Standley \& Steyermark (1943) described the petals of S. megistanthus from Guatemala as $170-190 \mathrm{~mm}$ long, supposedly 'twice as long as any other member of the genus', two different flowers from the type collection with petals measuring 130 and $139 \mathrm{~mm}$ were seemingly ignored, one of which overlaps with petals 132 $\mathrm{mm}$ long exhibited by a collection from Nicaragua (Schatz \& Stevens 587). Similarly, Fries (1930) described the petals of S. borealis from Sinaloa, Mexico, as $25-33 \mathrm{~mm}$ long despite one flower on the type collection with petals $44 \mathrm{~mm}$ long. He later annotated another Sinaloa collection (Ortega 6695) with petals to $55 \mathrm{~mm}$ long as $S$. borealis 'petala longa', which falls within the range of variation in petal length exhibited in Nicaragua. Pedicel length is also highly variable, exhibiting nearly as much variation in a single collection (12-33 $\mathrm{mm}$ long for Schatz \& Stevens 586 from Nicaragua) as the total variation of $6-43 \mathrm{~mm}$ manifest throughout the total distribution range, thus easily encompassing the $28-35 \mathrm{~mm}$ long pedicels of the type of S. longipedunculatus (Langlassé 128bis) from Guerrero, Mexico.

\section{Sapranthus viridiflorus G.E.Schatz - Fig 3d, e; Map 1}

Sapranthus viridiflorus G.E.Schatz (1998) 436. - Type: Schatz 963 (holo MO; iso CR, DUKE, NY, WIS), Costa Rica, Heredia, La Selva Biological Station of the Organization for Tropical Studies, $4 \mathrm{~km} \mathrm{~S}$ of Puerto Viejo de Sarapiquí, 35 m, 15 Feb.1984.

Tree or rarely shrub 3-12 m tall, 10-25 cm diam; young twigs and petiole densely covered with erect and appressed, white hairs to c. $0.5 \mathrm{~mm}$ long, soon glabrous. Leaves: petiole $4-10$ $\mathrm{mm}$ long, $1-2 \mathrm{~mm}$ diam; lamina elliptic to obovate, $8-29$ by 
3-13 cm, sparsely covered with erect and appressed, white hairs to c. $0.5 \mathrm{~mm}$ long above, densely to rather densely so below, base acute to obtuse, or somewhat truncate, apex acuminate (acumen 10-20 mm long) to acute, venation weakly brochidodromous, primary vein impressed above, secondary veins $10-12$ on either side of primary vein, slightly raised above, tertiary veins slightly raised above, more or less percurrent. Inflorescence and flower indument: pedicels and outer side of bracts and sepals densely covered with erect and appressed, white hairs, petals sparsely so to glabrous. Flowers solitary, leaf-opposed, sometimes produced from leafless branches or from the main trunk; pedicels $10-15 \mathrm{~mm}$ long, $1-2 \mathrm{~mm}$ diam, to c. $20 \mathrm{~mm}$ long and c. $5 \mathrm{~mm}$ diam in fruit; bract leafy, ovate to elliptic, 4-9 by $3-5 \mathrm{~mm}$; sepals 6 - or 7 -veined, triangular, 6-8 by $4-7 \mathrm{~mm}$, reflexed; petals membranous with evident venation when young, becoming thick and fleshy and lacking evident venation at anthesis, green with a reddish purple tint at base inside, faintly 3-6-veined when dry, narrowly elliptic to narrowly ovate, $20-29$ by $5-15$, base cuneate, margins strongly revolute, apex acute, food body c. 2.5 by $4.5 \mathrm{~mm}$, broadly triangular, vestigial, i.e., lacking fleshy ridges, white. Monocarps 1-6, greyish green, pulp orange, oblongoid to ellipsoid, 50-100 by $30-60 \mathrm{~mm}$, wall $1-5 \mathrm{~mm}$ thick, stipes $0-5 \mathrm{~mm}$ long, 3-6 $\mathrm{mm}$ diam. Seeds $7-12$, in one or two rows, spherical wedgeshaped, $15-30$ by $3-10 \mathrm{~mm}$, smooth, pale brown.

Distribution - SE Nicaragua (Madriz, Río San Juan), Costa Rica (Alajuela, Cartago, Guanacaste, Heredia, Limón, Puntarenas), Panama (Bocas del Toro, Chiriquí, Los Santos, Veraguas).

Habitat \& Ecology — In moist to wet evergreen forest; from 0-1700 m. Flowering: January, February, July, September, October; fruiting: all year through.

Vernacular name - Panama: Hueve de caballe (Holdridge 6231).

Field observations - 'Frutos con olor de guanabana' (Alfaro 53, Costa Rica), 'frutos con olor como Anona' (Bello 1385, Costa Rica), 'flores de aroma fuerte muy agradable' (Herrera 1564, Costa Rica), 'flowers with 'horrible' smell of bananas' (Maas 7961, Costa Rica); 'flowers with strong smell of bananas' (Maas 7956, Costa Rica).

Note - Sapranthus viridiflorus differs from all other Sapranthus species by its green petals lacking visible venation at anthesis (which, however, clearly exhibit venation in bud and when dry), and the low number of monocarps (1-6).

Acknowledgements We are indebted to the curators of the following herbaria, from which we borrowed or studied material: B, BM, BR, C, CAS, CR, DUKE, F, FHO, G, GH, INB, L, LL, MEXU, MICH, MO, NY, P, PMA, S, STRI, TEX, U, UC, US, W, WAG, WIS, WU, XAL, Z. The distribution maps in this publication were created using ESRIs ArcMap software for Windows. The first author thanks R. Kiger and J. White at the Hunt Institute for Botanical Documentation for allowing him to study the Sessé and Mociño drawings and to reproduce two of the drawings herein. He also acknowledges support for field work from an NSF Doctoral Dissertation Improvement Grant BSR8511373, the George H.M. Lawrence Memorial Fund, the E.K. and O.N. Allen Herbarium Fund of the University of Wisconsin-Madison, the University of Wisconsin-Madison Natural History Museums Council, and the Davis Fund of the University of Wisconsin-Madison Botany Department. He is especially thankful for the mentorship and inspiration provided by the late H.H. Iltis.

\section{REFERENCES}

Baillon H. 1868. Histoire des plantes 1: 193-288. Hachette \& Cie, Paris, London, Leipzig.

Bawa KS. 1978. Chromosome numbers of tree species of a lowland tropical community. Journal of the Arnold Arboretum 54: 422-434.

Bentham G, Hooker JD. 1867. Genera Plantarum 1 (3): 955-958. Reeve \& Co., London.

Brandegee TS. 1913. Plantae mexicanae purpusianae. University of California Publications in Botany 4: 375-376.
Chaowasku T, Thomas DC, Van der Ham RWJM, et al. 2014. A plastid DNA phylogeny of tribe Miliuseae: Insights into relationships and character evolution in one of the most recalcitrant clades of Annonaceae. American Journal of Botany 101 (4): 691-709.

Chatrou LW, Pirie MD, Erkens RHJ, et al. 2012. A new subfamilial and tribal classification of the pantropical flowering plant family Annonaceae informed by molecular phylogenetics. Botanical Journal of the Linnaean Society 169: 5-40.

Donnell Smith J. 1895. Undescribed plants from Guatemala and other Central American Republics XIV. Botanical Gazette (Chicago) 20: 1-11.

Dunal MF. 1817. Monographie de la famille des Anonacées. Paris, Treutel \& Würtz.

Fries RE. 1900. Beiträge zur Kenntniss der Süd-Amerikanischen Anonaceen. Kongliga Svenska Vetenskapsakademiens Handlingar, n.s., 34 (5): 1-59.

Fries RE. 1930. Revision der Arten einiger Anonaceen-Gattungen I. Acta Horti Bergiani 10, 1: 1-128.

Fries RE. 1931. Revision der Arten einiger Anonaceen-Gattungen II. Acta Horti Bergiani 10, 2: 129-341, pl. 1-27.

Fries RE. 1948. New or noteworthy Annonaceae from tropical America. Kongliga Svenska Vetenskapsakademiens Handlingar, ser. 3, 24, 10: 3-19.

Fries RE. 1959. Annonaceae. In: Melchior H (ed), Die natürlichen Pflanzenfamilien ... begründet von A. Engler und K. Prantl, ed. 2, Band 17a II: 1-171. Duncker \& Humblot, Berlin

Hemsley WB. 1886. In: Hooker JD, Icones Plantarum pl. 1514. Longman, Orme, Brown, Green \& Longmans, London.

Hemsley WB. 1887. Biologia Centrali-Americana, Botany 4: 96 . Porter \& Dulau \& Co., London.

Humboldt FHA, Bonpland AJA, Kunth KS, et al. 1821. Nova genera et species plantarum 5: 55-65. Mazé, Paris.

Janzen DH. 1983. Sapranthus palanga. In: Janzen DH (ed), Costa Rican Natural History, University of Chicago Press, Chicago, IL.

Janzen DH, Martin PH. 1982. Neotropical anachronisms: the fruits the gomphotheres ate. Science 215: 19-27.

Maas PJM, Mennega EA, Westra LYT. 1994. Studies in Annonaceae XXI. Index to species and infraspecific taxa of neotropical Annonaceae. Candollea 49: 389-481.

McVaugh R. 1977. Botanical results of the Sessé \& Mociño Expedition (1787-1803). I. Summary of excursions and travels. Contributions of the University of Michigan Herbarium 11: 97-195.

McVaugh R. 1980. Botanical results of the Sessé \& Mociño Expedition (1787-1803). II. Icones Florae Mexicanae. Contributions of the University of Michigan Herbarium 14: 99-140.

McVaugh R. 1982. The lost paintings of the Sessé \& Mociño Expedition: a newly available resource. Taxon 31: 691-692.

McVaugh R. 1998. Historical introduction. In: White JJ, McVaugh R, Kiger RW, The Torner collection of Sessé \& Mociño biological illustrations. Hunt Institute for Botanical Documentation, Carnegie Mellon CD Press, Pittsburgh, PA.

Millspaugh CF. 1895. Contributions to the flora of Yucatan. Publications of the Field Columbian Museum, Botanical Series 1: 17.

Murray NA. 1993. Revision of Cymbopetalum and Porcelia (Annonaceae). Systematic Botany Monograph 40: 1-121.

Olesen JM. 1992. Flower mining by moth larvae vs. pollination by beetles and bees in the cauliflorous Sapranthus palanga (Annonaceae) in Costa Rica. Flora 187: 9-15.

Ortiz-Rodriguez AE, Ruiz-Suarez E, Ornelas JF. 2016. Phylogenetic relationships among members of the neotropical clade of Miliuseae (Annonaceae): generic non-monophyly of Desmopsis and Stenanona. Systematic Botany 41: 815-822.

Rose JN. 1897. Studies of Mexican and Central American plants. Contributions from the U.S. National Herbarium 5 (3): 134.

Safford WE. 1911. The rediscovery of the Xochinacatzli of the Aztecs, with notes on Mexican Anonaceae. Science n.s. 33: 470-471.

Schatz GE. 1987. Systematic and ecological studies of Central American Annonaceae. PhD thesis, University of Wisconsin-Madison.

Schatz GE. 1998. New species of Sapranthus B.C. Seemann and Unonopsis R.E. Fries (Annonaceae) from Mesoamerica. Novon 8: 436-440.

Schatz GE, Maas PJM. 2010. Synoptic revision of Stenanona (Annonaceae). Blumea 55: 205-223.

Schatz GE, Maas PJM, Maas-van de Kamer H, et al. 2018. Revision of the Neotropical genus Desmopsis (Annonaceae). Blumea 63: 67-86.

Seemann B. 1866. On Sapranthus, a new genus of Annonaceae, from Central America. Journal of Botany 4: 369.

Standley PC. 1922. Trees and shrubs of Mexico. Contributions from the United States National Herbarium 23, 2: 171-515.

Standley PC, Steyermark JA. 1943. Studies of Central American plants - III. Field Museum of Natural History, Botanical series 23, 1: 7-8. 
Ter Welle BHJ, Van Rooden J. 1982. Systematic wood anatomy of Desmopsis, Sapranthus, and Stenanona (Annonaceae). IAWA Bulletin 3: 15-23.

Vélez-Arango JG, Cogollo-Pacheco A. 2007. Primer registro del género Sapranthus (Annonaceae) y una nueva especie para suramérica. Caldasia 29: $229-233$.

\section{IDENTIFICATION LIST}

$\begin{array}{lll}\text { camp }=\text { S. campechianus } & \text { hirs }=S . \text { hirsutus } \\ \text { chia }=\text { S. chiapensis } & \text { isae }=S . \text { isae }\end{array}$

Acosta 161: pala; 855: pala - Aguilar 365: viol; 1171: viol - Aguilar F. 4208: viri; 8000: viri; 8021: viri - Alfaro 53: viri - Allen 6202: hirs - Almeda 4198: pala; 4212: pala - Alonso 19: micr - Alvarenga 181: viol - Alvarez 279: camp; 11077: camp - Andrieux 476: micr - Araquistain 2861: pala; 3479: viol - Arellanes C. 139: viol - Arvigo 263: camp - Atwood 1907: pala Avendano 211: micr - Avila 176: micr - Ayala 38: micr

Bacab 83: camp - Balick 1933: camp - Barclay 2015: viol - Bartlett 12298: camp; 12750: camp - Bello 1385: viri - Blake 7417: micr - Boucher 725: pala - Breedlove 6364: camp; 47988: sp. indet.; 50135: viol - Brown 82: camp - Burger 11377: pala; 11388: pala; 12040: viri.

Cabrera 3502: camp; 4965: camp; 6764: camp; 8761: camp; 8909: camp; 9894: camp; 11515: camp - Calderón 325: micr; 422: viol; 1471: viol; 2239 : micr; 14715: viol - Calzada 1057: micr; 9330: micr - Carballo 212: micr Carlson 2140: camp - Cascante 185: pala - Chan 2597: camp - Chavarría 606: pala - Chinchilla ISB00047: micr; ISB00263: micr; ISB00338: micr Contreras 355: camp; 5439: camp; 6089: camp; 6126: camp; 8416: camp; 8685: camp; 8690: camp - Conzatti 3111 (= Reko 3111): micr; 3226: viol; 4457: viol; 4503: viol - Cook 219: camp; 746: pala - Coronado 28: viol; 582: viol; 630: viol; 4210: viol; 5716: pala; 5964: pala; 6285: pala - Crane 411: camp - Croat 23556: camp; 24651: camp; 32795: micr.

Daubenmire 306: pala - Davidse 30531: viol - Dawe 73-0613: pala - Dawson 6035: micr - Deago 346: viri - Dodge 6663: pala - Donnell Smith 1484: micr; 4508 (leg. Heyde \& Lux): micr; 4519 (leg. Heyde \& Lux): viol - Dorantes 1082: micr; 1183: micr; 1197: micr; 5230: micr - Duran 3465: camp.

Echeverria 286: pala - Edwards P-332: micr - Enriquez 196: camp - Escuela Nacional de Ciencias Forestales Siguatepeque 2602: viol - Espinoza 41: viri.

Fallon 2602: pala - Fernandez 1668: pala - Flores, J. 394: viol - Flores, R. 1932: camp; 9951: camp - Forment 829: viol; 1116: viol - Förther 10853: viol - Fournier 907: viri - Frankie 86a: pala; 86c: pala; 400a: viri; 400c: viri - Friedrichsthal 1062: pala.

Galan 1444: micr; 1807: micr; 2802: micr - Gallardo 160: viri - GarciaMendoza 46: micr; 1686: micr - Garnier 676: pala; 919: pala; s.n. (possibly the same as 676 or 919): pala - Garwood 534: pala - Gaumer 71: camp; 1094: camp; 23995: camp - Gentle 27: camp; 193: camp; 1261: camp; 3980: camp; 4752: camp - Gentry 373: pala; 8310: camp; 71443: pala German 268: viol - Gomez-Laurito 9994: viri; 11367: viri - Gomez-Pompa 60/94: camp - Gongora 843: camp; 911: camp; 957: camp - González 4052: camp; 4878: camp - Gonzalez Ortega 856: viol - Granados 118: camp - Grayum 4503: viri; 5555: viri; 5695: viri; 6092: pala; 11480: pala Greenman 5807: pala; 5931: viol - Grijalva 704: pala; 815: pala; 1733: viol; 2424: pala; 2626: viol; 2683: viol; 4094: viol; 5948: hirs - Guzmán 163: pala.

Haber 11916: viri - Hammel 10620: viri; 11601: viri; 22451: pala - Hartshorn 1096: viri - Hazlett 2602: viol - Heithaus 15: pala - Hernández ES-56: camp; 251: micr - Hernández, F. 629A: viri - Herrera 754: viri; 1564: viri; 2203: viri - Hinton 4564: viol; 9102: viol; 9182: viol; 10318: viol; 10340: viol; 10343: viol; 10344: viol - Hoffmann 366: pala - Holdridge 6231: viri - Hughes 1916: viol.

Ibarra 2164: micr; 3779: sp. indet.; 5659: micr - Iltis G-63: viol.

Janzen 11710: pala - Jiménez, O. 908: pala; 992: pala - Jiménez Madrigal 1766: viri - Jones 24: viol

Kellerman 5660: viol; 6614: viol - Kral 69353: pala - Kruse 1101: viol.

Langlassé 128bis: viol - Leon 875: pala - Lépiz 170: viri - Liesner 4355: pala - Linares 1296: viol; 7528: micr - López s.n. (ISF00271): viol - Lott 1854: micr; 3132: micr; 3203: micr; 3332: viol; 3418: micr; 3432: micr; 3464: micr; 3649: micr; 3772: micr - Lundell 490: camp; 4752: camp; 7450: camp; 17106: camp; 19238: camp.

Maas 7956: viri; 7961: viri; 8450: viol; 8457: micr; 9402: viri - Martínez, V. 56: micr; 155: sp. indet.; 625: viol; 761: viol; 876: viol; s.n. (CMC00625): viol - Martínez Calderon 1496: viol - Martínez Salas 30952: camp; 31399: camp - Matuda 16420: chia; 16466: chia; 17296: micr; 17436: micr; 17486: micr; 18681: micr - May 154: camp - Méndez 385: camp - Mendoza 1686: micr - Merello 3627: micr - Miranda 5109: camp; 5189: micr; 5271: camp;
Waha M, Hesse M. 1988. Aperture types within Sapranthus and Polyalthia (Annonaceae). Plant Systematics and Evolution 161: 135-146.

Waha M, Morawetz W. 1988. Pollen evolution and systematics in Annonaceae with special reference to the disulcate Australian endemic genera. Plant Systematics and Evolution 161: 1-12. micr $=$ S. microcarpus

pala $=$ S. palanga

\author{
viol $=S$. violaceus \\ viri $=S$. viridiflorus
}

5985: micr; 6007: micr; 6677: camp; 9120: micr; 9141: micr-Molina R. 105: viol; 555: micr; 715: micr; 856: viol; 1222: micr; 2577: micr; 2997: micr; 3210: micr; 3401: micr; 3571: micr; 8637: viol; 13001: micr; 13657: hirs; 14203: viol; 23110: viol; 31680: micr - Monro 1951: micr; 2160: viol; 2763: viol; 3483: viol - Morales 1733: viri; 2770: viri; 2915: pala; 8014: pala-Morales Can 2062: viol - Moreno 9436: viol; 9654: viol; 15969: pala; 16265: viol; 16275: viol; 21246: viol; 21967: viol; 22891: viol; 24176: viol; 24182: viol; 25555: viri - Morton 2531: micr - Murray 1450: micr.

Nee 28265: viol - Neill 3142: pala; 3612: viri; 4636: pala - Nelson, C. 302: micr; 3500: micr; 6420: viol; 6781: micr; 6894: micr; 7588: micr; 13719: micr - Nelson, E. 2443: micr; 6977: viol.

Oersted 157: pala; 158: pala; 158b: pala; 5863: pala - Ortega 856 (= Narvaez 856): viol; 4948: viol; 6619: viol; 6695: viol - Ortíz, O. 1635: viri - Ortíz, R. 1894: camp; 1997: camp; 2564: camp.

Palmer 394: viol - Pérez-García 862: micr - Pérez-Jiménez 175: viol; 661: viol; 1358: viol - Pittier 1519: pala; 13404 (= Donnell Smith 7576): viri Plowman 3018: pala - Polanco 2795: viri - Popenoe 714: viol; 764: viol - Poveda 84: viri; 300: pala - Puch 1159: camp; 1218: camp - Purpus 421: micr; 6276: micr.

Quesada 38: viri - Quigley 906: pala.

Raven 20993: pala; 20994: pala - Record G132: viol - Reko 3226: viol; 4914: viol - Reyes-Garciá 4681: micr - Rico 697: camp - Rivera 543: viri - Rivera Díaz 3940: isae - Robleto 438: pala - Rodríguez, D. 1519: micr; 1550: micr; 2124: viol; 2336: viol; 2548: micr; 2788: micr; 2880: micr; 3455: micr; 4133: micr; 4613: micr - Rodríguez G. 2297: viri - Roe 1337: camp - Rosales 162: viol; 165: micr; 447: viol; 466: micr; 573: micr; 703: viol; 723: micr; 738: viol; 1240: micr; 1902: micr - Rosas 640: micr - Rose 1453: viol; 1842: viol - Rovirosa 521: camp - Rueda 1191: viol; 9708: viri; 11915: viol; 12947: viol; 13887: viol; 15972: viol.

Salas, J. 667: viol; 1414: micr - Salas, S. 322: pala - Sanabria-Sima 252: camp - Sandino 1895: pala; 1968: pala; 2811: pala; 3219: pala; 3818: viol; 4393: viol; 4426: viol; 4437: viol - Sandoval 120: micr; 1455: micr; s.n. (MS00342): micr; s.n. (MS00359): viol - Santamaría 2510: viri - Santiago Gómez 735: viol - Schatz 586: viol; 587: viol; 963: viri; 1031: viri; 1199: micr - Schott 559: camp - Seemann s.n. (or possibly Seemann 4): viol Sessé 2321: viol - Shannon s.n. (Donnell Smith 5041): viol - Simá 1315: camp - Smith, A. P2492: pala - Smith, C. 111: viol - Smith, D. 283: viri - Solano 1308: viri - Solis Magallanes 3842: micr; 4063: micr - Solomon 2602: pala - Sousa 5578: viol; 11241: camp - Soza 98: viol; 396: viol; 407: pala - Sperry 1972: viri - Standley 3156: micr; 3359: micr; 6845: micr; 15184: viol; 19692: micr; 19992: micr; 20393: viol; 20851: viol; 21223: micr; 21398: micr; 21622: micr; 21817: micr; 22099: viol; 22268: micr; 22329: micr; 22598: viol; 26495: micr; 28036: viol; 44911: pala; 54270: camp; 55030: camp; 56483: micr; 59219: viol; 68397: micr; 74430: viol; 74441: viol; 74502: viol; 74537: viol; 75595: viol; 79445: micr; 79684: micr; 87604: viol; 87640: viol - Steggerda 46a: camp - Stevens 20308: viol; 21938: pala; 22420: viol; 24881: viri; 28423: viol; 29623: viol; 30314: viol; 31353-A: pala; 31767: viol; 31798: viol; 32796: pala; 33997: viol - Steyermark 31103: viol; 42733: viol - Stork 2804: pala.

Tapia 1037: camp; 1935: camp - Tenorio 15569: viol - Thomsen 1152: viri; 1385: viri - Tonduz 8355: viri; 13138: viri; 13796: pala - Torres 4145: micr; 4766: micr; 8323: micr - Toval 443: viol; 483: viol - Turner 0-67: viol. Ucán 815: camp; 1434: camp.

Van Rooden 200: viol; 820: viol; 822: viol; 850: hirs; 866: pala; 867: pala; 868: pala; 869: pala; 874: pala - Vargas 141: isae; 192-A: isae - Velásquez 230: pala - Vélez 6339: isae; 6675: isae; 6687: isae; 6688: isae; 6689 : isae - Vincelli 480: viol; 709: viol - Von Türckheim 474: viol.

Walker 132: viri; 153: pala; 364: viri - Wallnöfer 5925: camp; 9652: camp Wendt 5661: viol - Williams 16766: viol; 18038: micr; 18053: hirs; 42473: viol; 42936: viol - Witsberger 302: viol.

Yuncker 6035: micr.

Zamora 1154: viri. 


\section{INDEX}

Accepted names are in roman type. New names are in bold type. Synonyms are in italics. The number after each name is the number of the species as used in this revision. References to pages are given in square brackets.

\author{
Asimia campechiana Kunth 1 \\ insularis Hemsl. 1 \\ Asimina campechiana Kunth 1 \\ foetida Rose 7 \\ insularis Hemsl. 1 \\ nicaraguensis (Seem.) Hemsl. 7 \\ purpusii Brandegee 5 \\ Porcelia microcarpa Donn.Sm. 5 \\ nicaraguensis (Seem.) Benth. \& Hook.f. 7
}

\author{
Sapranthus Seem. [p. 55] \\ sect. Microsapranthus R.E.Fr. [p. 56] \\ sect. Sapranthus [p. 56] \\ sect. Eu-Sapranthus [p. 56] \\ borealis R.E.Fr. 7 \\ campechianus (Kunth) Standl. 1 \\ chiapensis Standl. ex G.E.Schatz 2 \\ foetidus (Rose) Saff. 7 \\ hirsutus Van Rooden ex G.E.Schatz 3 \\ isae J.G.Vélez \& Cogollo 4 \\ ligularis Saff. ex R.E.Fr. 5
}

\author{
Sapranthus (cont.) \\ longipedunculatus R.E.Fr. 7 \\ megistanthus Standl. \& Steyerm. 7 \\ microcarpus (Donn.Sm.) R.E.Fr. 5 \\ nicaraguensis Seem. 7 \\ palanga R.E.Fr. 6 \\ var. santaerosae R.E.Fr. 6 \\ violaceus (Dunal) Saff. 7 \\ viridiflorus G.E. Schatz 8 \\ Unona violacea Dunal 7 \\ Uvaria nicaraguensis (Seem.) Baill. 7 \\ purpurea 7
}

\section{LIST OF VERNACULAR NAMES}

Ala de murcielago (viol)

Anona (micr)

Anona blanca (viol)

Anonilla (camp)

Anonillo (camp, micr, viol)

Asta (micr, viol)

Asta de bajillo (micr)

Asta de costa (micr, viol)

Asta de media altura (viol)

Bastard Custard Apple (camp)

Boy Job (camp)

Cacao (viol)

Canjuro (micr)

Chac Elemuy (camp)

Chac Nich Max (camp)

Chacmax (camp)
Ché ku'uk xib'al (camp)

Chufle (micr)

Cojon de Venado (camp)

Coloradillo (micr)

Colorado (micr)

Elemuy (camp)

Flora de mula negra (viol)

Ganiste Tsub (camp)

Guacoco blanco ó tresillo (micr)

Guinea (pala)

Hasta (viol)

Hasta arbusto (micr)

Haste (chia)

Hazche (camp)

Hueve de caballe (viri)

Huevo de iguana (micr)
Kanistetsub (camp)

Lancewood (camp)

Morsiegalo (viol)

Nitxmaxche (camp)

Palanca (pala, viol)

Palanco (camp, micr, pala, viol)

Pataste de Mico (chia)

Platanito (viol)

Platano (pala)

Saramuyo silvestre (camp)

Sufricaya (camp)

Turru (pala)

Tuspi del monte (camp)

Zac Elemuy (camp)

Zopilote (viol)

Zopilotillo (viol) 